\title{
GUSTAVO COELHO RODRIGUES
}

\section{Caracterização ultraestrutural de células do sangue de cordão umbilical de bovinos azebuados}

Dissertação apresentada ao Programa de Pósgraduação em Anatomia dos Animais Domésticos e Silvestres da Faculdade de Medicina Veterinária e Zootecnia da Universidade de São Paulo, para a obtenção do título de Mestre em Medicina Veterinária

\section{Departamento:}

Cirurgia

Área de Concentração:

Anatomia dos Animais Domésticos e Silvestres

Orientador:

Profa. Dr. José Roberto Kfoury Júnior

São Paulo 
Autorizo a reprodução parcial ou total desta obra, para fins acadêmicos, desde que citada a fonte.

DADOS INTERNACIONAIS DE CATALOGAÇÃO-NA-PUBLICAÇ̃̃O

(Biblioteca da Faculdade de Medicina Veterinária e Zootecnia da Universidade de São Paulo)

T.1339 Rodrigues, Gustavo Coelho

FMVZ Caracterização ultraestrutural de células de sangue de cordão umbilical de bovinos azebuados / Gustavo Coelho Rodrigues. - São Paulo : G. C. Rodrigues, 2003.

$72 \mathrm{f}$ : : il.

Dissertação (mestrado) - Universidade de São Paulo. Faculdade de Medicina Veterinária e Zootecnia. Departamento de Cirurgia, 2003.

Programa de Pós-graduação: Anatomia dos Animais Domésticos e Silvestres.

Área de concentração: Anatomia dos Animais Domésticos e Silvestres.

Orientador: Prof. Dr. José Roberto Kfoury Júnior.

1. Bovinos. 2. Sangue. 3. Cordão umbilical. 4. Ultraestrutura. 5. Microscopia eletrônica. I. Título. 


\section{UNIVERSIDADE DE SÃO PAULO \\ Faculdade de Medicina Veterinária e Zootecnia \\ Cidade Universitária "Armando de Salles Oliveira" \\ Comissão Bioética \\ CERTIFICADO}

Certificamos que o Projeto intitulado "Caracterização ultraestrutural de células do sangue de cordão umbilical de bovinos azebuados", Protocolo n $348 / 2003$, sob a responsabilidade do Prof. Dr. José Roberto Kfoury Júnior, utilizando úteros colhidos em matadouros, está de acordo com os princípios éticos de experimentação animal da Comissão de Bioética da Faculdade de Medicina Veterinária e Zootecnia da Universidade de São Paulo e foi aprovado pela referida Comissão, em sessão de 03/09/2003.

(We certify that the Research "Ultraestructural characterization of umbilical cord blood cells of bovines" protocol number 348/2003, under the responsibility of Prof. Dr. José Roberto Kfoury Júnior, utilizing uterus of the butcheries, agree with Ethical Principles in Animal Research adopted by Bioethic Commission of the Faculty of Veterinary Medicine and Zootechny of University of São Paulo and was approved in September/03/2003 meeting.

São Paulo, 08 de setembro de 2003

Profa Drá Júlia hiaria Materaca

Presidente da Comissão de Bioética

FMVZ/USP 
Nome: Rodrigues, Gustavo Coelho

Título: Caracterização ultraestrutural de células do sangue de cordão umbilical de bovinos azebuados.

Dissertação apresentada ao Programa de Pósgraduação em Anatomia dos Animais Domésticos e Silvestres da Faculdade de Medicina Veterinária e Zootecnia da Universidade de São Paulo para obtenção do título de Mestre em Medicina Veterinária

Data:

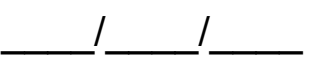

Banca Examinadora

Prof. Dr. Instituição:

Julgamento: Assinatura:

Prof. Dr. Instituição:

Julgamento: Assinatura:

Prof. Dr. Instituição:

Julgamento:

Assinatura: 
Dedico este trabalho In memorian: ao meu avô, Walter Rodrigues Ferrini, e à minha avó, Maria Aparecida Machado Coelho, pelo exemplo de vida e de caracter traduzidos em um consistente alicerce familiar. 


\section{AGRADECIMENTOS}

Ao Prof. Dr. José Roberto kfoury Jr., pela amizade e orientação na realização deste trabalho.

Ao Prof. Dr Pedro Primo Bombonato, por ter me recebido neste Departamento.

Ao Prof. Dr Idércio Luiz Sinhorim pela valiosa ajuda na interpretação dos resultados.

A Prof. Dr ${ }^{a}$ Mariz Vainzof , por viabilizar o processamento do material no laboratório do genoma humano.

Aos meus amigos e colegas de trabalho, do LITIAM, Janaina, Laura, Lilian, Mônica e Patrícia pela companhia, amizade, espírito de grupo e ajuda imprescindível na realização deste projeto.

À Gabriela e Patrícia, colegas de turma do curso de Pós-Graduação, pela amizade e presteza durante todo o curso.

A todos amigos do curso de Pós-Graduação pela companhia, amizade e auxílio no decorrer deste período.

Aos meus pais Walter Piva Rodrigues e Maria Regina Coelho Rodrigues e aos meus irmãos Mariana e Rafael, pela amizade e companheirismo em mais este desafio.

À minha namorada, Rafaela Kammuller d'Almeida pela ajuda e pela compreensão durante todo este percurso, tornando-o mais brando.

À Alexandre Kammuller d'Almeida pela ajuda na formatação do trabalho. 
Ao Colega e amigo Zohair Saliem Sayegh, pelo apoio e incentivo durante a minha vida acadêmica e início de vida profissional.

A todos meus familiares, que sempre me incentivaram e apoiaram nos novos desafios, representados pelo meu avô materno Antônio Coelho e minha avó paterna Cleonilde Piva Rodrigues. 
RESUMO

Rodrigues, G. C. Caracterização ultraestrutural das células de sangue de cordão umbilical de bovinos azebuados. [Ultraestructural characterization of umbilical cord blood of bovine]. 2003. 72 f. Dissertação (Mestrado em Ciências) Faculdade de Medicina Veterinária e Zootecnia, Universidade de São Paulo, São Paulo, 2003.

Estudos envolvendo a utilização do sangue de cordão umbilical foram intensificados na última década, devido ao grande potencial que estas possuem nas pesquisas de transplantes e ontogenia celular. A investigação dos métodos para a purificação e caracterização dessas células em diferentes animais pode aumentar a utilização destes como modelos experimentais para uma variedade de propostas científicas e terapêuticas. Para desenvolver a caracterização das células de sangue de cordão umbilical foram utilizadas 20 amostras oriundas de fetos de com idades compatíveis ao segundo e terceiro terço de gestação. Estas amostras foram processadas de duas formas distintas. A primeira forma visou às células presentes na camada leucocitária total, a segunda visou as células com densidade menor que 1077 separadas pelo Ficoll Paque. Os "pellets" resultantes foram processados para posterior observação por microscopia eletrônica de transmissão. Foram constatadas a presença de células granulares (basófilos, eosinófilos e neutrófilos) e agranulares (células bláticas, precursores eosinofílicos e linfócitos) em diferentes estágios de maturação em ambos os grupos e também células com características morfológicas compatíveis a apoptose.

Palavras Chave: Bovinos. Sangue. Cordão umbilical. Ultraestrutura. Microscopia eletrônica 


\begin{abstract}
Rodrigues, G. C. Ultraestructural characterization of umbilical cord blood of bovine. [Caracterização ultraestrutural de células do sangue de cordão umbilical de bovinos azebuados]. 2003. 72 f. Dissertação (Mestrado em Ciências) - Faculdade de Medicina Veterinária e Zootecnia, Universidade de São Paulo, São Paulo, 2003.
\end{abstract}

Studies involving the use of umbilical cord blood were intensified in the last decade, due to its huge potential for transplant research and the ontogeny of leucocytes cells. The investigation of the methods to purify and characterize these cells in different animals are a base for experimental models for a variety of scientific and therapeutic proposals. To develop the characterization of the umbilical cord cells, twenty samples of fetal were collected. The fetal were in the second and third thirds of the gestation. These samples were processed in two distinct forms. The first form, studied the cells in the buffet coat. The second, studied the cells with density less than, 1,077 separated by the Ficoll Paque. The resulting pellets were processed for later observation by electronic microscopy transmission. The presence of granular and non granular cells were detected in different maturation stages in both groups and also morphological compatible cells with apoptosis.

Palavras Chave: Bovine. Blood. Animal umbilical cord. Ultraestructural. Eletronic microscopic. 


\section{LISTA DE FIGURAS}

Figura 1 - Gráfico da hematopoiese

Figura 2 - Eletrofotomicrografia de tarnsmissão de células presentes na camada leucocitária total. Polimorfonucleares (PMN), células da série linfocíticas (setas vermelhas), células em apoptose (seta azul). Apresentando uma vesícula nuclear ( $v)$ e fragmentos do núcleo (f). (Escala da barra $=2 \mu \mathrm{m})$.

Figura 3 - Célula com característica morfológica sugestiva de um precursor eosinofílico presente na Camada Leucocitária Total. Núcleo contem nucléolo $(n)$, em seu citoplasma contem dois tipos de grânulos $\mathrm{Gr}(1)$ e $\mathrm{Gr}(2)$. O $\mathrm{Gr}(2)$ possui estruturas lamelares(em evidência). (Escala da barra $=500 \mathrm{~nm}-$ barra em evidência $=$ 200nm)

Figura 4 - Polimorfonuclear presente na Camada Leucocitária Total. Seu núcleo apresenta um nucléolo ( $n$ ) com três tipos distintos de grânulos $\operatorname{Gr}(1), \operatorname{Gr}(2)$ e $\operatorname{Gr}(3)$. Em evidência, nota-se os diferentes tipos de grânulos. (escala da barra $=500 \mathrm{~nm}$, barra em evidência $=200 \mathrm{~nm}$ )

Figura 5 - Célula com características morfológicas compatíveis a um precursor basofílico presente na Camada Leucocitária Total. Em seu citoplasma nota-se a presença de grânulos $(\mathrm{Gr})$ com alta eletrodensidade (escala da barra $1 \mathrm{~cm}=2 \mu \mathrm{m}$ ).

Figura 6 - Fotomicrografia de células blásticas $(1,2,3)$ presentes na Camada Leucocitária Total. Alta relação núcleo:citoplasma. No núcleo nota-se a presença de nucléolos ( $\mathrm{n})$. No citoplasma estão dispersos mitocôndrias. (Escala da barra $=1 \mathrm{~cm}=2 \mu \mathrm{m}$ ).

Figura 7 - Fotoeletromicrografia de um bastonete presente na interface de Ficoll 1077. Nota-se a presença de um nucléolo. Em seu citoplasma estão dispersos grânulos (Gr) de formas arredondadas e longilíneas, com eletrodensidades semelhantes. (escala da barra $=500 \mathrm{~nm})$.

Figura 8 - Fotoeletromicrografia de um polimorfonuclear presente na interface de Ficoll 1077. Nota-se a presenç a de grânulos $\operatorname{Gr}(1)$ e $\mathrm{Gr}(2)$ distintos pela eletrodensidade. $\operatorname{Gr}(1)$ apresenta eletrodensidade menor comparada ao $\mathrm{Gr}(2)$, estes possuem estruturas lamelares em seu interior. (Escala da barra $=500 \mathrm{~nm}) \ldots 54$ 
Figura 9 - Fotomicrografia de células presentes na interface do Ficoll 1077. Nota-se a presença de células precursoras eritrocíticas (er), seu núcleo possui formato oval e sua cromatina muito condensada. Nota-se a presença de mitocôndrias dispersas em seu citoplasma. Células com características compatíveis a linfócitos são observadas (lo). (Escala da barra $=1 \mathrm{~cm}=2 \mu \mathrm{m})$.

Figura 10 - Fotomicrografia de uma célula precurssora eritrocítica presente na interface de Ficoll 1077. Nota-se um núcleo redondo com a cromatina muito condensada. Em seu citoplasma nota-se a presença de vesículas de endocitose (v). (Escala da barra = $500 \mathrm{~nm})$

Figura 11 - Fotomicrografia de um linfócito presente na interface do Ficoll 1077 (Escala da barra $=500 \mathrm{~nm})$

Figura 12 - Fotomocrografia de uma célula com seu núcleo em forma de trevo de quatro folhas. Presente na interface de Ficoll 1077. (Escala da barra $=500 \mathrm{~nm})$

Figura 13 - Presença de células com características de um precursor granulocítico (Pgr). Seu núcleo apresenta-se com formato redondo ou oval $(\mathrm{N})$, apresentando cromatina densa (Escala da barra $=2 \mu \mathrm{m})$ 
SUMÁRIO

1 INTRODUÇÃO 12

2 OBJETIVOS 15

3 REVISÃO DE LITERATURA 17

4 MATERIAL E MÉTODO 35

4.1 Animais utilizados 36

4.2 Obtenção do Material 37

4.3 Processamento do Material 38

4.4 Interpretação dos Resultados 40

5 RESULTADOS 41

6 DISCUSSÃO 60

7 CONCLUSÕES 66

REFERENCIAS $\quad 68$ 
1 INTRODUÇÃO 


\section{INTRODUÇÃO}

Dentro da área científica, estudos crescentes, principalmente em humanos, vêm envolvendo a utilização do sangue de cordão umbilical, devido à presença de células progenitoras hematopoéticas, que Ihe confere aplicabilidade em questões como terapias e transplantes.

Em seres humanos o sangue de cordão umbilical é tido como uma alternativa viável aos transplantes de medula óssea. A baixa incidência de doença de reação do hospedeiro contra o enxerto torna-o ainda mais atraente (ZAGO; SANTIS, 1998).

A presença de células precursoras agranulares comprometidas com o desenvolvimento de leucócitos conferem ao sangue de cordão relevante importância no estudo da ontogênese destas células, que se revela pouco conhecida (DVORACK; FURITSU; ISHIZAKA, 1993).

Em animais domésticos, esta área científica vem se desenvolvendo, buscando aprimorar o conhecimento médico. Algumas pesquisas enfocam a importância do conhecimento animal para a prática da medicina humana, como Ladgies (1990) e Niemeyer (2001) que citam o cão como um modelo pré-clínico para o desenvolvimento de novas alternativas no transplante de medula óssea.

Em bovinos, particularmente, são escassos os trabalhos relacionados a este assunto, porém, sabe-se que o receptor Kit e seu ligante, "Stem Cell Factor" (SCF), estão presentes nas células envolvidas nos estágios iniciais da granulopoiese em bezerros (HIKONO et al., 2001). 
O estudo de métodos para a purificação e caracterização de células progenitoras hematopoéticas em diferentes animais pode aumentar a utilização destes, como modelos experimentais, para uma variedade de propostas científicas e terapêuticas.

Da mesma forma, a interação do conhecimento morfofisiológico em diferentes espécies pode elucidar mecanismos funcionais ainda não bem estabelecidos, assim como beneficiar a própria espécie quanto à suas patologias, desenvolvimento e exploração.

A caracterização morfológica ultraestrutural se faz necessária para um maior conhecimento dos tipos celulares aqui presentes, servindo assim como uma base de conhecimento que impulsionará o desenvolvimento desta linha de pesquisa nos animais e em paralelo às pesquisas realizadas em seres humanos. Em bovinos, esta pode se desenvolver na utilização deste como um modelo experimental para meios de cultura, na investigação da ontogenia de leucócitos, na produção de anticorpos monoclonais para células progenitoras hematopoéticas, as quais são encontrada em grande quantidade no sangue de cordão umbilical; enfim, a plasticidade desta linha de pesquisa é imensa. Cabe lembrar que o Brasil possui uma atividade pecuária extensiva de corte abundante, que garante a facilidade na obtenção de amostras para o desenvolvimento de pesquisas nesta espécie animal. 
2 OBJETIVOS 


\section{OBJETIVOS}

O presente projeto possui como objetivo a caracterização ultraestrutural das células do sangue de cordão umbilical através da microscopia eletrônica de transmissão, a fim de proporcionar informações necessárias para embasar e auxiliar no desenvolvimento dessa linha de pesquisa em bovinos. 
3 REVISÃO DE LITERATURA 


\section{REVISÃO DE LITERATURA}

Em mamíferos a conexão entre o embrião (feto) e a placenta é representada pelo cordão umbilical, cuja função principal é o transporte de nutrientes do organismo materno para o fetal e de catabólitos no sentido inverso.

O cordão umbilical de bovinos mede em torno de 40 - 45 centímetros e está completamente envolto pelo âmnio. A extremidade do cordão umbilical forma uma estrutura saliente e a extremidade corial marca a expansão dos vasos e o infundíbulo inicial do alantóide (MONTANÉ; BOURDELLE, 1917). Os vasos sanguíneos junto a outras estruturas constituem o cordão umbilical, apresentando-se ao número de quatro sendo duas artérias e duas veias (BARONE, 1986; MONTANÉ; BOURDELLE, 1917). Em bovinos azebuados ocorre uma anastomose inter arterial em $93.33 \%$ dos casos (RIBEIRO, 1995).

Histologicamente o cordão umbilical é formado por um epitélio do tipo escamoso estratificado com cornificações em estruturas semelhantes a papilas (LATSHAW, 1987).

No início do desenvolvimento embrionário aparece um tecido hematógeno na esplancnopleura extra-embrionária do saco vitelíneo. Esse tecido é representado, de inicio, por ninhos de células mesenquimais chamadas hemangioblastos, que em conjunto recebem o nome de ilhotas de Wolff. Os hemangioblastos centrais de cada ilhota de Wollf darão origem aos hemocitoblastos, responsáveis pela formação de todas as células do sangue, sendo também chamados de "stem cells" (células tronco). Uma percentagem da população de hemocitoblastos diferencia-se em eritroblastos muito grandes (megablastos), que entram no embrião através dos 
vasos que também estão sendo formados. Os hemocitoblastos que não se diferenciam em megablastos, na circulação, alojam-se no fígado, timo e baço. No fígado os hemocitoblastos originam as hemácias, plaquetas, granulócitos e monócitos, ocorrendo, ainda, o recrutamento de linfócitos B e linfócitos T originados, respectivamente, no fígado e timo, que se alojam em áreas histológicas específicas deste órgão, caracterizando-o como um órgão linfóide secundário. Concomitantemente à fase de ossificação do esqueleto e durante toda a vida do indivíduo, os hemocitoblastos são segregados na medula óssea, onde originam todos os elementos figurados do sangue (GEORGE; ALVES; CASTRO, 1998).

As células sangüíneas podem ser classificadas em células linfóides ( $T, B$ e natural killers) e mielóides (granulócitos, monócitos, eritrócitos e megacariócitos) (GUNSILLUS; GASTL; PETZER, 2001).

Todas as células sangüíneas, como descrito anteriormente, são derivadas de um "pool" comum de células pluripotentes, chamadas Células Tronco Pluripotentes (CTP) ou Célula Tronco Hematopoética (CTH), com a capacidade de proliferação, replicação e diferenciação. Em resposta a estímulos específicos, a CTH diferenciase em células tronco mielóide ou linfóide, preservando sua capacidade pluripotente. As células tronco linfóide diferenciam-se em células precursoras pré - B ou pré - T. A célula tronco mielóide origina uma célula tronco intermediária denominada de CFU - GEMM (unidade formadora de colônia granulocitária, eritrocitária, monocitária, megacariocitária), que a partir de citocínas específicas, diferenciam-se em linhagens eritróide, megacariocítica, mielóide, monocítica, eosinófila e basófila (CARR, 2000; GUNSILLUS; GASTL; PETZER, 2001) 
Observa-se que a hematopoiese é um processo dinâmico e que as células amadurecem gradualmente de um estágio para o outro; a ilustração abaixo vem a elucidar tal observação.

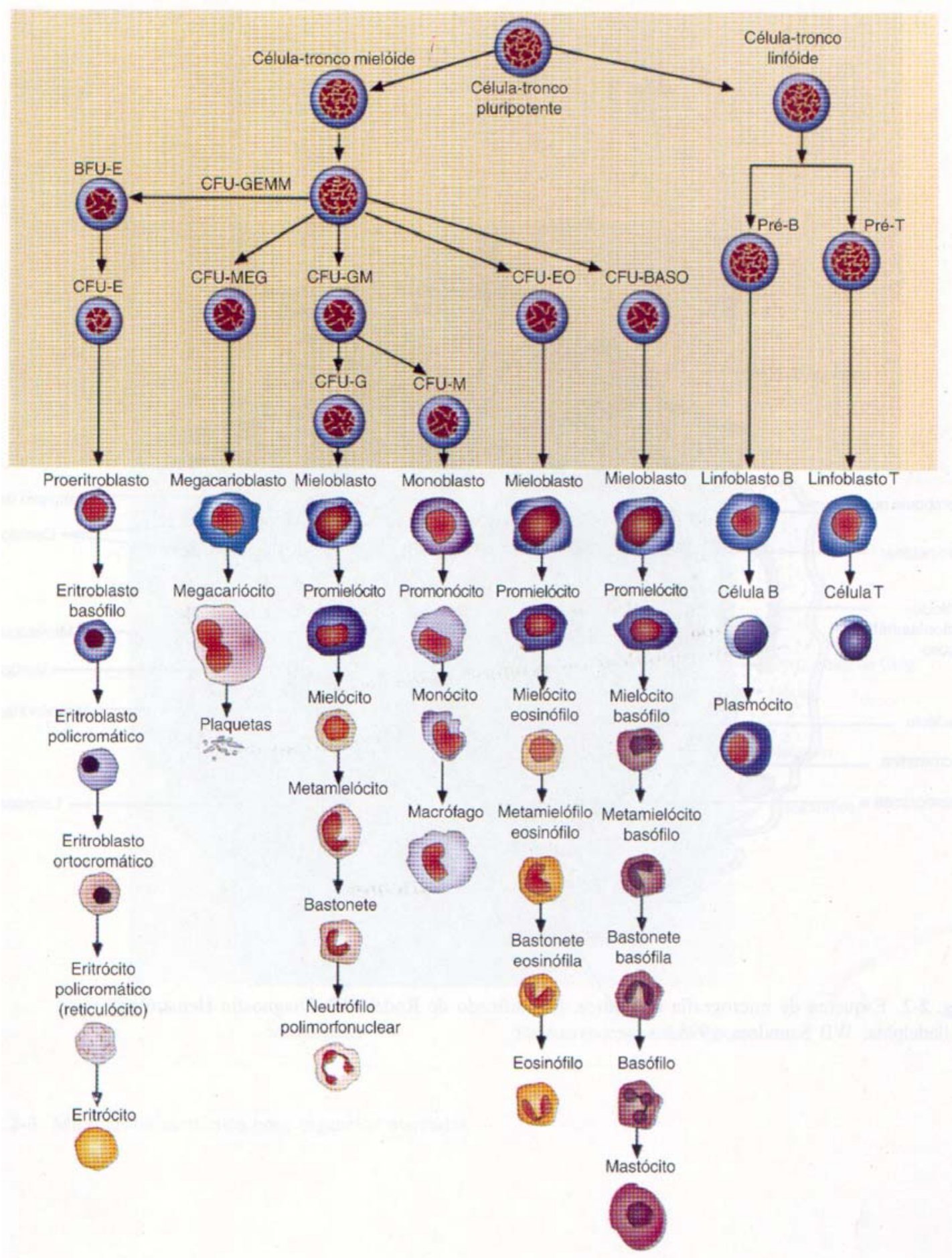

Figura 1 - Esquema representativo da Hematopoiese. Fonte: Carr, 2000 
As diferentes células das diversas séries sanguíneas apresentam características morfológicas de ultraestrutura distintas, evidentes mesmo nas células da mesma linhagem em seus diferentes estágios de maturação. Estas características tornam-se evidentes tanto na microscopia óptica quanto na microscopia eletrônica de transmissão.

As principais alterações morfológicas observadas no processo de maturação celular são; a diminuição da basofília citoplasmática, regressão no tamanho celular e condensação progressiva da cromatina (CARR, 2000).

Sendo assim as células da linhagem eritróide diferenciam-se até a célula matura, eritrócito, a partir do rubriblasto originando ordenadamente através de processo de maturação o prorubrícito, rubricito basofílico, rubricito policromático, metarrubrícito, reticulócito e finalmente o eritrócito. A nomenclatura da série eritrocítica permite a utilização de sinônimos que estão dispostos no Quadro 1.; ressaltamos que os termos aqui utilizados condizem com as recomendações feita em Jain (1993c).

Quadro 1. Nomenclatura para identificação morfológica das células da série eritrocítica

\begin{tabular}{ll}
\hline Termo recomendado & Outros termos \\
\hline Rubriblasto & Pronormoblasto, proeritroblasto \\
Prorubrícito & $\begin{array}{l}\text { Normoblasto basofílico (ou jovem) ou } \\
\text { eritroblasto basofílico } \\
\text { (incluir termos da categoria acima) }\end{array}$ \\
Rubricito basofílico & Normoblasto policromático jovem ou \\
Rubricito policromático & eritroblasto \\
Metarrubrícito & Normoblasto policromático maturo ou \\
& eritroblasto, normoblasto ortocromático \\
& ou eritroblasto \\
Reticulócito & Eritrócito policromático \\
Eritrócito & Células vermelhas do sangue e célula \\
& vermelha \\
\hline
\end{tabular}

Fonte: Jain (1993c) 
A maturação eritrocítica envolve além da enucleação, ocorrendo na fase compreendida pelo metarrubrícito e o reticulócito, a perda da capacidade mitótica, uma progressiva diminuição no tamanho da célula e de seu núcleo, aumento na condensação da cromatina, a diminuição da basofília do citoplasma e aumento na policromasia, seguido pela normocromasia (DESSYPRIS, 1993; JAIN, 1986; JAIN, 1993c).

Morfologicamente o rubriblasto é reconhecido pela dimensão relativamente grande, $15-20 \mu \mathrm{m}$, núcleo redondo com a cromatina fina e pontilhada, com a presença de um ou mais nucléolos. Seu citoplasma apresenta um complexo de Golgi bem desenvolvido, muitos ribossomos, polirribossomos e mitocôndrias. Poucos filamentos de retículo endoplasmático rugoso (R.E.R) e moléculas de ferritina espalhadas, molécula que auxilia na identificação da célula como pertencente da série eritrocítica. O prorubrícito pode apresentar início de condensação da cromatina e a ausência do nucléolo ou mesmo possuir um nucléolo pequeno. Em seu citoplasma contêm muitos ribossomos e polirribossomos e vestígios de R.E.R. (DESSYPRIS, 1993; JAIN, 1986; JAIN, 1993c).

O rubricito, célula subseqüente ao prorubrícito na maturação, apresenta a cromatina ligeiramente condensada. Seu citoplasma pode se apresentar corado de azul, caracterizando o rubricito basofílico ou de azul - acinzentado caracterizando o rubricito policromático. $\mathrm{O}$ rubricito matura-se originando o metarrubrícito, este apresenta o núcleo redondo com a cromatina totalmente condensada. O reticulócito, originado da maturação do metarrubrícito, apresenta-se como uma célula anucleada com muitos ribossomos e polirribossomos, mitocôndrias também são visíveis no citoplasma destas células. Raramente sobram outras organelas de modo que 
centríolos e complexo de Golgi podem ser observados, com exceção do retículo endoplasmático (DESSYPRIS, 1993; JAIN, 1986; JAIN, 1993c).

O processo de maturação do reticulócito em eritrócito pode ocorrer tanto no sangue periférico como no fígado. Este processo envolve alterações morfológicas, como uma ligeira perda da superfície da membrana e a alteração de receptores de superfície como a tranferrina e fibronectina. No citoplasma há uma diminuição de ribossomos e de outras organelas. Nota-se a obtenção do conteúdo normal de hemoglobina, a redução do tamanho celular e a mudança para a forma bicôncova (DESSYPRIS, 1993; JAIN, 1986; JAIN, 1993c).

Um aspecto comum na hematopoese de todas as espécies mamíferas é que os eritrócitos são nucleados e grandes na fase inicial da vida intra-uterina e, com o avanço da gestação, os eritrócitos apresentam-se anucleados e menores seguindo este modelo até poucos meses após o nascimento. A contagem leucocitária é baixa durante o início da vida fetal, aumentando gradualmente a quantidade de neutrófilos e linfócitos a medida que o feto se desenvolve (JAIN, 1993c). Alsalami e Filippich (1999), demonstraram experimentalmente, utilizando fetos de ovinos, que durante as primeiras quatro semanas de desenvolvimento os eritroblastos constituíam a maioria das células sangüíneas circulantes.

Eritrócitos definitivos originados no fígado aparecem na circulação por volta do $27^{\circ}$ dia de gestação. Seu número aumenta rapidamente, excedendo a quantidade de eritroblastos por volta do $50^{\circ}$ dia de gestação. A população de células vermelhas não nucleadas em fetos com idade superior a 50 dias de gestação é caracterizada por reticulócitos e eritrócitos. A quantidade de reticulócitos foi numerosa a partir do $49^{\circ}$ dia de gestação diminuindo a sua proporção para menos de $1 \%$ quando o 
feto está a termo. O número de Leucócitos aumentou consideravelmente a partir do $49^{\circ}$ dia de gestação, os linfócitos foram às primeiras células a serem vistas no sangue e permaneceram como a principal população celular nucleada durante toda a gestação. As plaquetas estavam presentes em todos os fetos, aumentando muito em quantidade após o $68^{\circ}$ dia de gestação.

Na medula óssea de fetos com menos de 70 dias, observou-se pouca evidência de hematopoiese, contudo após este período muitas células blásticas estavam presentes (ALSALAMI; FILIPPICH, 1999).

Alsalami e Filippich (1999) destacam, ainda, a predominância da eritropoiese sobre a mielopoiese, megacaricitopoiese e linfopoiese na medula dos ossos examinados até o $122^{\circ}$ dia de gestação. A granulopoiese esteve presente na hematopoiese da medula óssea a partir do $75^{\circ}$ dia de gestação até o termino desta.

A maturação celular observada na medula óssea assemelhou-se a do fígado (ALSALAMI; FILIPPICH, 1999).

Na medula óssea de fetos humanos com 11 a 22 semanas de gestação já se observa atividade hematopoética. As células granulocíticas compreendem cerca de $23 \%$ de todas as células nucleadas na $11^{a}$ a $12^{a}$ semana de gestação. Estes aumentam para $43 \%$ nas $21^{a}$ a $22^{a}$ semana, sendo a maior parte dos granulócitos constituída por neutrófilos. $\mathrm{Na} 21^{\mathrm{a}}$ a $22^{\mathrm{a}}$ semana de gestação os granulócitos representam 52\% dos três principais grupos hematopoéticos, granulocítico, linfocítico e eritrocítico. No estágio inicial do desenvolvimento as células eritrocíticas representam cerca de $12 \%$ do total das células nucleadas na cavidade dos ossos, aumentando sua concentração com a idade, atingindo cerca 
de $18 \%$ na $17^{a}$ - $22^{a}$ semana de gestação. Nos adultos chegam a $30 \%$ (CARBONELL; CALVO; FIEDNER, 1982).

Carbonell; Calvo e Fiedner (1982) relatam que os linfócitos e linfoblastos aparecem cedo na medula óssea aumentando seu número progressivamente a partir da $11^{\mathrm{a}}$ a $18^{\mathrm{a}}$ semana, chegando a representar cerca de $19 \%$ de todas as células nucleadas na $17^{\mathrm{a}}-18^{\mathrm{a}}$ semana mantendo esta proporção até $22^{\mathrm{a}}$ semana de gestação. A porcentagem de linfócitos na medula óssea de adultos é bem menor cerca de $8 \%$.

A quantidade de células megacariocíticas oscilou muito pouco no período observado, variando de $0.58 \%$ na fase inicial a $1,2 \%$ na $22^{a}$ semana. As células monocíticas aparecem em pequena quantidade variando de 0,6 até $1,1 \%$ (CARBONELL; CALVO; FIEDNER, 1982).

Em sangue periférico de fetos humanos, com 1,9 cm de crown-rump (CR), 99\% das células vermelhas observadas eram nucleadas, a termo este valor declina para cerca de $0.02 \%$ das células nucleadas. Células semelhantes ao mielócito foram encontradas em fetos com $1,9 \mathrm{~cm}(\mathrm{CR})$ representando $15 \%$ do total de leucócitos. Já a presença de polimorfonucleares maturos foi observada pela primeira vez em fetos com 4,2 cm de (CR). Células maturas e precursoras foram encontradas em quantidade semelhante em fetos acima de $17 \mathrm{~cm}$ de (CR) (20 semanas), após este período células precursoras foram raramente encontradas (PLAYFAIR; WOLFENDALE; KAY,1963).

Os granulócitos: eosinófilos, basófilos e neutrófilos originam-se a partir de células bipotenciais comprometidas com a formação de granulócitos e monócitos, unidade formadora de colônia - granulócito e monócito (CFU-GM) que, sob efeitos 
específicos, diferenciam em células unipotentes, unidade formadora de colôniagranulócito (CFU-G) e unidade formadora de colônia-monócito (CFU-M) responsáveis pela produção de precursores granulocíticos e monocíticos respectivamente (GUNSILLUS; GASTL; PETZER, 2001; JAIN, 1993f). O mieloblasto é o primeiro precursor granulocítico. Caracteriza-se morfologicamente como uma célula imatura, apresentando um núcleo redondo com a cromatina fina, com a presença de um ou mais nucléolos. O volume citoplasmático varia entre modesto a abundante, sua coloração é moderadamente basofílica devido à distribuição abundante e uniforme de partículas de ribonucleoproteína, e é agranular. Observase a presença de pequenas mitocôndrias distribuídas pelo citoplasma e a presença inconstante de reticulo endoplasmático, que se apresenta sob a forma de uma vesícula alongada, achatado e grande (ATHENS, 1993a; CAPONE, 1964; JAIN, 1993f).

A maturação dos mieloblastos em promielócitos é evidenciada pelas mudanças no núcleo e citoplasma do próximo estágio. Nos promielócitos, o núcleo apresenta uma cromatina ligeiramente mais grosseira que a do mieloblasto e uma menor evidência dos nucléolos. No citoplasma o retículo endoplasmático granular é mais numeroso e possui uma forma que varia de arredondada a oval, diferente do aspecto achatado nos mieloblasto. As mitocôndrias apresentam-se um pouco menos numerosas. Observa-se o início da presença de grânulos redondos, densos e homogêneos. Estes grânulos azurofílicos preenchem o citoplasma e constituem os primeiros grânulos a aparecer num granulócito em desenvolvimento. O promielócito apresenta, quando jovem um núcleo com uma cromatina difusa que se torna mais grosseira, quando este alcança um estágio mais avançado. A condensação da cromatina dá - 
se ao redor da periferia do núcleo e extendende-se resultando em áreas de cromatina aglutinada (ATHENS, 1993a; CAPONE, 1964; JAIN, 1993f).

O mielócito, estágio subseqüente da maturação, é marcado pela presença de grânulos secundários específicos às diferentes linhagens celulares: em eosinofílica, basofílica e neutrofílica (ATHENS, 1993a; CAPONE, 1964; JAIN, 1993f).

O núcleo do mielócito apresenta variação no formato, de arredondado a oval, com poucos dentes. O nucléolo não está mais presente nesta fase e sua cromatina é mais condensada. Seu citoplasma possui muitos grânulos secundários e poucos primários (ATHENS, 1993a; CAPONE, 1964; JAIN, 1993f).

O metamielócito, célula proveniente da maturação do mielócito, possui núcleo chanfrado. A membrana nuclear é bem definida, sua cromatina é grosseira e não há presença de nucléolos. Neste estágio de maturação, poucas mitocôndrias são vistas. Nota-se a presença de complexo de um complexo de golgi bem desenvolvido e de um retículo endoplasmático limitado a vesículas esparsas, muitas vezes pouco evidentes devido à presença de muitos grânulos. A última fase da maturação granulocítica é contemplada pelos bastonetes, células com o núcleo não segmentado em forma de bastão contraído, sem apresentar torções, formando segmentos. Nota-se também a presença de pequenas agregações de cromatina. Seu citoplasma é abundante com poucos grânulos primários e muitos secundários (ATHENS, 1993a; CAPONE, 1964; JAIN, 1993f).

Os grânulos presentes no citoplasma celular são capazes de diferenciar as células precursoras e maturas da série granulocítica, como foi dito anteriormente (CAPONE, 1964; JAIN, 1993f). 
Sendo assim, os neutrófilos possuem dois tipos de grânulos; os azurófilos ou primários e os específicos ou secundários e, diferenças na quantidade destes grânulos marcam os diferentes estágios da maturação neutrofílica. Os grânulos primários se sobrepõem aos secundários na fase celular imatura, ocorrendo o inverso a patrir do mielócito. Morfologicamente são distintos, os grânulos primários são relativamente grandes, mais eletrodensos, arredondados e menos pleomórficos do que os secundários (ATHENS, 1993a; CAPONE, 1964; JAIN, 1993f).

As técnicas rotineiras de coloração não coram os grânulos primários, devido à redução de glicosaminoglicano nos grânulos, no entanto, os grânulos primários coram-se positivamente com mieloperoxidase e negativamente para fosfatase alcalina. Já os secundários coram-se com a fosfatase alcalina, mas não com a peroxidase (ATHENS, 1993a; JAIN, 1993f).

Ambos os grânulos são produzidos pelo complexo de Golgi e sempre encaminhados para os lisossomos (ATHENS, 1993a; JAIN, 1993f).

Os eosinófilos maturos caracterizam-se pelo núcleo polimórfico menos segmentado quando comparado ao do neutrófilo. Sua cromatina é grosseira e agrupada. Nos promielócitos eosinofílicos observam-se uma quantidade maior de grânulos azurofílico grandes em contraste com os delicados grânulos dos promielócitos neutrofílicos. Na microscopia eletrônica estes grânulos aparecem homogêneos e eletrodensos. Com o avançar da maturação os grânulos homogêneos transformamse em grânulos cristalóides, com o núcleo eletrodenso, ou se mantêm homogêneo, porêm tornam-se mais compactos. Estes dois tipos de grânulos cristalóides e homogêneos caracterizam o eosinófilo (ATHENS, 1993b; CAPONE; WEINREB; CHAPMAN, 1964; EGESTEN et al., 1997; JAIN, 1993b). 
Os felinos e suínos apresentam os grânulos cristalóides, os cães grânulos parcialmente cristalóides enquanto os bovinos e eqüídeos apresentam somente grânulos homogêneos (JAIN, 1993b).

Os grânulos dos basófilos na sua fase imatura apresentam - se homogêneos na microscopia eletrônica. $\mathrm{Na}$ fase matura podem estar presentes partículas eletrodensas dispostas como fibrilas ou lamelas ou forma de favo de mel (JAIN, 1993a).

Os grânulos dos basófilos são envolvidos por uma membrana claramente trilaminar, com aproximadamente $75 \AA$ de espessura, esta membrana sempre apresenta interrupções. Estes grânulos oscilam muito em tamanho, variando de 1000 Å a mais de $1 \mu \mathrm{m}$. Em algumas células, grânulos parcialmente dissolvidos, ocasionalmente, continham cristais que apresentavam-se fusiformes em secção longitudinal e hexagonais na secção transversal (HASTINE; CHIR, 1974).

A série monocítica tem como precursor o monoblasto, que é uma célula de difícil caracterização morfológica, no entanto, possui núcleo redondo com contorno ondulado ou denteado. Sua cromatina pode ser pontilhada ou rendilhada com um ou mais nucléolos distintos, pouco eletrodenso, característica de núcleos imaturos. Seu citoplasma é escasso ou moderadamente abundante, apresenta muitas mitocôndrias redondas e tem seu retículo endoplasmático com aspecto semelhante ao do mieloblasto, alongado e achatado. Partículas de ribonucleoproteínas estão abundantemente espalhadas pelo citoplasma e vesículas de complexo de Golgi assumem padrão circular de distribuição na região de identação do núcleo (ATHENS, 1993; CAPONE; WEINREB; CHAPMAN, 1964; JAIN, 1993e). 
O promonocito, estágio antecessor ao monócito, apresenta um núcleo com mais convoluções, que tende a ser mais denteado ou alongado com a maturação celular. Sua cromatina é rendilhada e o nucléolo desaparece neste estágio. O citoplasma torna - se mais abundante e passa a ter alguns vacúolos (CAPONE; WEINREB; CHAPMAN, 1964; JAIN, 1993e).

O monócito maturo é caracterizado por seu núcleo pleomórfico, que pode assumir várias formas. Em geral possui convoluções semelhantes a do cérebro, sua cromatina é filamentosa, rendilhada, exibindo áreas de condensação. O citoplasma apresenta-se relativamente abundante, com alguns grânulos azurofílos, alguns poliribossomos espalhados, podendo apresentar pseudópodes também. Próximo ao núcleo existe feixes de microfilamentos que são caracteristicos do promonocito e monócito (CAPONE; WEINREB; CHAPMAN, 1964; JAIN, 1993e).

Os linfócitos originam-se diretamente de células tronco linfóide originando células pré B e pré $\mathrm{T}$ que conseqüentemente se diferenciaram em linfoblasto $\mathrm{T}$ e linfoblasto B originando, assim, os linfócitos T e B respectivamente (JAIN, 1993d).

Os linfócitos podem ser caracterizados em pequenos $(6-9 \mu \mathrm{m})$ ou grandes $(9-15$ $\mu \mathrm{m})$ ou considerando seu tempo de vida podem ser de curta ou longa duração. Na base imunológica podem ser classificados em B (bursa-dependente) ou T (timo dependente) e non-T, non-B ou null cells (PARASKEVAS; FOERSTER, 1993; JAIN, 1993d). Na maioria das espécies, 80 - 95\% dos linfócitos do sangue periférico são classificados como células T e B (PARASKEVAS; FOERSTER, 1993; JAIN, 1993d).

O linfócito imaturo, linfoblasto, caracteriza-se morfologicamente como uma célula grande, com citoplasma basofílico e cromatina lisa. A presença de um ou mais 
nucléolos, nesta condição, caracteriza o linfoblasto (PARASKEVAS; FOERSTER, 1993; JAIN, 1993d).

O linfócito maturo caracteriza-se morfologicamente pelo núcleo redondo ou oval, podendo ser ligeiramente chanfrado com a cromatina variando de condensada a muito condensada e pode ou não apresentar nucléolo. Seu citoplasma varia de escasso a moderado, podendo apresentar vacúolos e ocasionalmente grânulos azurofilos (PARASKEVAS; FOERSTER, 1993; JAIN, 1993d).

As células tronco hematopoéticas (CTH) apresentam-se cada vez mais em evidência no cenário da medicina mundial, graças a sua utilidade clínica frente ao tratamento de doenças neoplásicas e não neoplásicas (GUNSILLUS; GASTL; PETZER, 2001; WYNTER; TESTA, 2001; ZAGO; SANTIS, 1998).

\footnotetext{
As fontes tradicionais de CTH são a medula óssea, sangue periférico de indivíduos submetidos a mobilização com quimioterapia e/ou utilização de fatores de crescimento e sangue de cordão umbilical (GUNSILLUS; GASTL; PETZER, 2001; WYNTER; TESTA, 2001; ZAGO; SANTIS, 1998).
}

Nos últimos anos, o sangue de cordão umbilical (SCU) estabeleceu-se como alternativa fonte de CTH para transplantes (ROSLE et al, 2000; WYNTER; TESTA, 2001). O primeiro transplante de CTH de SCU ocorreu em 1989 em uma receptora com anemia de Fanconni, sendo a doadora uma irmã HLA-idêntica (GLUCKMAN et al, 1998; MAYIANI; LANSDROP, 1988; ZAGO; SANTIS, 1998).

Células com marcador de membrana $\mathrm{CD} 34^{+}$contemplam células primitivas (células tronco) e células hematopoéticas já comprometidas com uma linhagem celular: células progenitoras (GUNSILLUS; GASTL; PETZER, 2001; WYNTER; TESTA, 2001; ZAGO; SANTIS, 1998).

No sangue de cordão de seres humanos as células CD34 representam cerca de 1\% das células nucleadas, semelhante ao estimado para medula óssea (MAYIANI; 
LANSDROP, 1988; WYNTER; TESTA, 2001). No entanto no início da gravidez a freqüência de células CD34 é muito maior, por volta de 11\%, decrescendo com o tempo de gestação (MAYIANI; LANSDROP, 1988; WYNTER; TESTA, 2001; ZAGO; SANTIS, 1998).

Outros marcadores são utilizados para caracterizar célula tronco hematopoética como CD38, Thy-1+, c-kit, Rh, CD45RA, CD71 (GUNSILLUS; GASTL; PETZER, 2001; MAYIANI; LANSDROP, 1988; WYNTER; TESTA, 2001; ZAGO; SANTIS, 1998).

Caracterizando - a imunofenotipicamente a CTH mais primitiva como CD34+, CD38-, CD45RAlo, CD71lo, Thy-1+, c-Kit fraco, Rh fraco ( MAYIANI; LANSDROP, 1988).

As células progenitoras hematopoéticas da medula óssea, sangue periférico e sangue de cordão umbilical vem sendo amplamente caracterizadas tanto funcionalmente quanto molecularmente, mas suas características ultraestruturais são pouco estudadas. Principalmente em células separadas imunomagnéticamente com anticorpo monoclonal CD 34+ (DELILIERS et al., 2001).

Mikami et al. (2002) estudando as características ultraestruturais de células de sangue de cordão umbilical de seres humanos relata a presença de células morfologicamente imaturas, como mielócitos e promielócitos. Poucos mieloblastos foram observados. Estes apresentavam o núcleo de formato redondo, cromatina frouxa e nucléolo grande, seu citoplasma era escasso e apresentava poucas organelas, como descrito por Capone, Weinreb e Chapman (1964) e Jain (1993f). Mikami et al. (2002) sugere que as diferenças morfológicas entre as células tronco do sangue de cordão e as células tronco da medula óssea podem interferir na proliferação e regeneração celular após o transplante de célula tronco. 
Os granulócitos observados por Mikami et al. (2002) apresentavam particularidades em sua ultraestrutura. Nos neutrófilos observou características morfológicas de apoptose, evidenciadas pela marginalização da cromatina na forma de capuz e a presença de cromatina condensada. Foram observados em alguns eosinófilos grânulos com cristais, a presença de um núcleo cristalóide é vista no processo de maturação dos grânulos eosinofílicos, e basófilos em degeneração devido a aparência lamelar de seus grânulos.

Na população linfocítica do sangue de cordão umbilical observada por Mikami et al. (2002) apresentava linfócitos atípicos com formato nuclear de trevo de quatro folhas compatíveis com células presentes em portadores da Síndrome de Sezary e de indivíduos adultos acometidos por leucemia de células T. Foi observada a presença de linfócitos imaturos com nucléolo no sangue de cordão umbilical. A presença de células da linhagem eritrocítica no sangue de cordão umbilical também foi relatada; tanto eritroblastos, caracterizados pela cromatina condensada e citoplasma escuro, devido ao acumulo de hemoglobina quanto eritrócitos contendo mitocôndrias foram observados freqüentemente; sugerindo uma intensa eritropoiese.

As plaquetas observadas no sangue de cordão umbilical apresentaram-se com diâmetro maior que $10 \mu \mathrm{m}$, porem, estas células não estão presentes no sangue periférico (MIKAMI et al., 2002).

Deliliers et al. (2001) promoveu a separação magnética de células CD $34^{+}$de medula óssea, sangue periférico e sangue de cordão umbilical estas células foram, posteriormente, marcadas por citoquímica para mieloperoxidase e conseguinte observação na microscopia eletrônica de transmissão. As células CD $34^{+}$de sangue periférico apresentaram-se morfologicamente homogêneas e com 94,7\% das células 
mieloperoxidase negativa, característica ultraestrutural considerada típica de célula imatura.

As células $\mathrm{CD} 34^{+}$de medula óssea apresentaram-se mais heterogêneas, com $24,6 \%$ demonstrando intensa atividade da mieloperoxidase. Já as células CD $34^{+}$de sangue de cordão umbilical apresentaram alta porcentagem de células morfologicamente imaturas sem evidencias de atividade da mieloperoxidase. $\mathrm{O}$ número de células em apoptose das amostras das diferentes origens avaliadas pela microscopia eletrônica de transmissão demonstrou uma porcentagem maior de células em apoptose na medula óssea (2.3\%) em comparação ao sangue periférico. O sangue de cordão umbilical apresentou diferenças estatísticas referentes a células em apoptose proveniente de amostras obtidas em parto normal ou em cesariana. Estas representavam 2,9 \% e 11,6 \% respectivamente das células observadas. Sugerindo uma redução na viabilidade das células tronco de amostras provenientes de cesariana (DELILIERS et al., 2001). 
4 MATERIAL E MÉTOdO 


\section{MATERIAL E MÉTODO}

\subsection{Animais utilizados}

Foram coletadas 20 amostras, destas, 10 amostras são provenientes de animais com idade fetal compatível ao segundo terço de gestação e o restante de animais de terceiro terço de gestação. Animais com idade fetal compatível com o primeiro terço de gestação impossibilitaram a coleta de um volume sangüíneo adequado para o processamento do material. A idade fetal foi estimada pela medida do crow-rump (Tabela 1), de acordo com Noden e Lahunta (1990).

Tabela 1 - Idade dos fetos de acordo com o crow-rump. São Paulo, 2003

\begin{tabular}{lcc}
\cline { 2 - 3 } Animal & Crown Rump (cm) & Idade Fetal (dias) \\
\hline 1 & 43 & 165 \\
2 & 37 & 154 \\
3 & 75.5 & 230 \\
4 & 49 & 178 \\
5 & 47 & 172 \\
6 & 45 & 170 \\
7 & 48 & 176 \\
8 & 69 & 222 \\
9 & 53 & 185 \\
10 & 48 & 176 \\
11 & 42 & 162 \\
12 & 55 & 190 \\
13 & 72 & 226 \\
14 & 70 & 225 \\
15 & 74 & 229 \\
16 & 67 & 213 \\
18 & 75 & 230 \\
19 & 69 & 222 \\
20 & 80 & 240 \\
\hline
\end{tabular}


O material coletado foi transportado à temperatura ambiente até o laboratório por um período médio de 4 horas.

\subsection{Obtenção do Material}

A coleta das amostras de sangue do cordão umbilical foi realizada no frigorífico Mantiqueira Ltda, localizado na região metropolitana de São José dos Campos, Estado de São Paulo. O material coletado foi transportado à temperatura ambiente até o laboratório por um período médio de 4 horas.

De acordo com o procedimento deste frigorífico, os animais são dessensibilizados através do uso de pistola pneumática, sendo realizada a sangria e a introdução das carcaças na linha de abate. No momento da evisceração, os úteros gravídicos foram coletados para o processamento imediato, fora da linha.

Os úteros foram incisados na região da curvatura maior, para exposição do feto e seu cordão umbilical. O sangue foi coletado mediante a punção direta das veias do cordão umbilical utilizando-se agulhas de calibre $40 \times 12$ ou $25 \times 7$ e seringas plásticas de 5, 10 ou $20 \mathrm{~mL}$, de acordo com o calibre do vaso, contendo Adenosina Citrato Fosfato Dextrose (CPDA) na proporção de $1 \mathrm{~mL}$ de CPDA para cada $7 \mathrm{~mL}$ de sangue de cordão umbilical (SCU). A quantidade de sangue coletada variou de acordo com a idade do feto e o intervalo de tempo para a obtenção da amostra. 


\subsection{Processamento do Material}

No laboratório todas as amostras foram processadas com a utilização do FicollPaque 1077 (Amersham Pharmacia Biotech AB - Uppsala Sweden), visando a separação de células mononucleares de baixa densidade e por ser esta a densidade de escolha para separação das células com fenótipo CD 34+ nas diversas espécies ( FRITSCH et al., 1991; DELILIERS et al., 2001; NIEMEYER et al., 2001; PERTOFT, 2000) e sem a utilização deste.

As amostras de sangue processadas com Ficoll Paque (1077) foram diluídas em PBS- na mesma proporção completando um volume de $10 \mathrm{~mL}$. Esta solução foi despejada cuidadosamente em um tubo de "Coostar" (20mL) contendo $3 \mathrm{~mL}$ de Ficoll Paque, até completar o volume total de $13 \mathrm{~mL}$, formando um visível gradiente de densidade. A amostra foi centrifugada a $2000 \mathrm{rpm} \times 30 \mathrm{~min} \times 20^{\circ} \mathrm{C}$, a camada foi retirada com a ajuda de uma pipeta de Pasteur e realizada três lavagens com $\mathrm{PBS}^{-}$a $1500 \mathrm{rpm} \times 5^{\prime} \times 20^{\circ} \mathrm{C}$. Em seguida a amostra foi submetida a uma reação com solução de lise $(0,830 \mathrm{~g}$ de cloreto de amônio, $0,16 \mathrm{~g}$ de bicarbonato de sódio, 200 $\mu \mathrm{L}$ 0,5M EDTA ph 8,00 e q.s.p. $100 \mathrm{~mL}$ de água destilada) durante 15 minutos, a solução de lise foi desprezada restando somente um "pellet".

Este foi, então, submetido a três lavagens com PBS ${ }^{-}$a $1300 \mathrm{rpm} / 5^{\prime} / 20^{\circ} \mathrm{C}$. O "pellet" resultante foi então ressuspendido em $1 \mathrm{~mL}$ de $P B S^{-}$e transferido para um microtubo (Eppendorf ${ }^{\circledR}$ ) e centrifugado a $2000 \mathrm{rpm} / 5^{\prime} / 20^{\circ} \mathrm{C}$. O sobrenadante foi desprezado e o "pellet" resultante foi fixado em solução de Karnowisky (glutaraldeído 2,5\% e Paraformoldeído, $0,16 \mathrm{~g}$ em $2 \mathrm{ml}$ de água destilada) pelo período de 1 hora e lavado 6 vezes com sacarose a um intervalo de 10 minutos. Todo este processo foi 
feito sobre o gelo após a última lavagem foi incubado pelo período de uma noite a $4^{\circ} \mathrm{C}$. Após este período a sacarose foi retirada e substituída pelo tetróxido de ósmio $1 \%$, pelo período de 1 hora, seguiu-se com a desidratação da amostra com uma série gradual de etanol $(30,50,70,90,100 \%)$ com um intervalo de 10 minutos entre elas, tendo sido repetida por três vezes consecutivas a série com etanol $100 \%$. A partir de então, a temperatura ambiente, a amostra foi submetida à nova desidratação com Óxido de Propileno por um intervalo de 10 minutos. Em seguida a amostra foi embebida em uma solução de Oxido Propileno e Sppur 1:1 durante 30' e durante 1 hora com resina Sppur pura. Após este período a resina foi novamente trocada e a amostra deixada por um período de mais ou menos 12 horas a baixa rotação. Em seguida a amostra foi incubada por um período de 72 horas a $37^{\circ} \mathrm{C}$.

As amostras não submetidas à separação por gradiente de densidade com Ficoll Paque (1077), não necessitaram de diluição sendo centrifugadas a $2500 \mathrm{rpm} / 15^{\prime} /$ $20^{\circ}$ C. A camada leucocitária foi retirada, seguindo com a reação de lise e o processamento da amostra para microscopia eletrônica de transmissão como previamente descrito.

Após o período de incubação foram feitos cortes ultrafinos (70 nanômetros) em micrótomo Leica Ultracut $\mathrm{R}$ e contrastados em nitrato de chumbo e acetato de uranila em tela de cobre de 200 mesh. E então observadas em microscópio eletrônico de transmissão. 


\subsection{Interpretação dos Resultados}

Os resultados obtidos foram divididos em dois grandes grupos, a saber:

A. Células presentes na Camada Leucocitária Total;

B. Células presentes nas amostras processadas com Ficoll Paque 1077;

com o intuito de obter uma caracterização morfológica dos tipos celulares presentes nos diferentes grupos. Uma vez que, o Ficoll Paque é utilizado na separação de células mononucleares de baixa densidade, onde estão presentes um maior número de células com marcador de superfície CD $34^{+}$. Em ambos os grupos as células foram separadas em dois subgrupos, o das células sem grânulos e o das células com grânulos.

Os grupos foram submetidos a análises qualitativas. Nesta, o enfoque foi direcionado às características morfológicas individuais das células observadas nos dois diferentes grupos.

Desta forma, foram avaliadas as características do núcleo, levando em consideração seu diâmetro, suas formas, tipo de cromatina, presença ou não de nucléolo.

Quanto ao citoplasma, foram descritos, de forma qualitativa, os seus constituintes como grânulos, mitocôndrias, ribossomos, polirribossomos, complexo de golgi, retículo endoplasmático liso ou rugoso.

Entendemos que com essas características é possível avaliar os diferentes tipos celulares presentes nos grupos por nós estudados neste trabalho. 
5 RESULTADOS 


\section{$5 \quad$ RESULTADOS}

$\mathrm{Na}$ Camada Leucocitária Total as células granulares apresentaram diâmetro variado, oscilando de 5,3 a $13 \mu \mathrm{m}$ (Figuras 2, 3, 4, 5). Seus núcleos possuíam formas distintas (oval, redondo, PMN). A cromatina presente nestas células não apresentou grandes variações na sua morfologia. Apresentando-se, em sua maioria, de forma grosseira ou moderadamente grosseira. Os grânulos observados possuíam características morfológicas distintas, com eletrodensidades e formas diferentes indicando a presença de dois tipos distintos. Desta forma, foram observados grânulos menores e menos eletrodensos comparados a um segundo tipo maior e mais eletrodenso, assim como os observados nas células granulares presentes nas amostras processadas com Ficoll Paque 1077. Exceto pela célula presente na Figura 4 que dispõe de três tipos distintos de grânulos em seu citoplasma. As características morfológicas observadas na série granulocítica remetem a presença de células nos diferentes graus de maturação celular.

As células agranulares pertencentes a este grupo apresentaram maior diversidade nnas suas características morfológicas, assim como observado nas células agranulares do outro grupo. Estas apresentaram diâmetro de 4,0 $\mu \mathrm{m}$ até 10,6 $\mu \mathrm{m}$. O núcleo das células se apresentaram com formato redondo ou oval. A cromatina também apresentou maior diversidade. Foram observadas células com a cromatina fina, moderadamente densa e grosseira. Caracterizando assim células em seus diversos graus de maturação (Figura 2 e 6).

As células granulares presentes nas amostras processadas com Ficoll Paque 1077 (Figuras 7, 8 e 13). Apresentaram diâmetro em torno de 5,0 a 6,0 $\mu \mathrm{m}$. Estas células 
possuíam formas distintas de núcleos (oval, redondo, bastonetes e polimorfonucleares). No entanto, a cromatina das células observada caracteriza-se em sua maioria como densa.

Os grânulos observados possuíam características morfológicas distintas, com eletrodensidades e formas diferentes indicando a presença de dois tipos distintos. Desta forma, foram observados grânulos menores e menos eletrodensos comparados a um segundo tipo maior e mais eletrodenso. Salientando as características morfológicas das células granulares, estas sugerem a presença de células pertencentes aos diversos graus de maturação da série granulocítica neste subgrupo.

As células agranulares se apresentaram com características morfológicas mais heterogêneas comparadas ao subgrupo anterior. O diâmetro oscilou de 4,0 $\mu \mathrm{m}$ até 7,0 $\mu \mathrm{m}$ e o tipo de cromatina, também, foi mais heterogêneo. Foram observadas células com cromatina fina até células com a cromatina mais grosseira. As células neste subgrupo apresentaram características morfológicas compatíveis com células nucleadas da série eritrocítica e da série linfocíticas (Figuras 9, 10, 11). Células com o núcleo em forma de "trevo de quatro folhas" compatíveis com células em apoptose, como citadas por Mikami et al. (2002), foram observadas neste subgrupo (Figura 12).

Seguem-se abaixo as características morfológicas das células compreendidas pelo Grupo A.

Na Figura 2, observam-se células com características de um polimorfonuclear (PMN), com 2 ou 3 lobos. A cromatina destas células apresenta-se grosseira e agrupada. Em seu citoplasma existe a presença de dois tipos de grânulos, 
distinguidos pela diferença da eletrodensidade apresentada pôr cada um. O grânulo com menor eletrodensidade, denominado gr1, e o com maior eletrodensidade denominado gr2. Observa-se uma discrepância na quantidade de grânulos dispersos no citoplasma, sugerindo a presença de diferentes PMN no sangue de cordão umbilical dos bovinos. O diâmetro dos PMN presentes nesta foto oscilou de 5,6 $\mu \mathrm{m}$ até $8,2 \mu \mathrm{m}$.

Destaca-se, também, a presença de células com características morfológicas compatíveis com a série linfocítica (setas vermelhas). Todas apresentam núcleo com formato oval com a cromatina grosseira e agrupada. A presença de nucléolos é observada na maioria destas células, insinuando um menor grau de maturação celular. O diâmetro destas células é em torno de 5,6 $\mu \mathrm{m}$.

As células identificadas com as setas azuis apresentam características morfológicas compatíveis com células em apoptose. Pode-se observar no núcleo de uma destas células a presença de uma vesícula nuclear (v) e fragmentos (f) soltos no citoplasma que se originaram destas vesículas, estes são observados em ambas.

Na Figura 3, observa-se uma célula com características morfológicas sugestivas de um precursor eosinofílico. Seu núcleo é oval com a cromatina fina, nota-se a presença de um nucléolo (n). Em seu citoplasma observa-se a presença grânulos redondos com estruturas, em seu interior, de eletrodensidade maior a dos grânulos que as contêm (em destaque). Estas características dos grânulos aqui presentes remetem à as observadas nos grânulos eosinofílicos. A célula apresenta diâmetro de $5,5 \mu \mathrm{m}$. 
Na Figura 4, observa-se a presença de uma célula com diâmetro de 5,5 $\mu \mathrm{m}$. Seu núcleo é característico de um PMN, com dois lobos, sua cromatina é grosseira e agrupada e destaca-se a presença de um nucléolo (n). Seu citoplasma é preenchido pôr três tipos morfologicamente distintos de grânulos identificados como gr1, gr2 e gr3. O gr1 apresenta-se arredondado e pálido, com a menor eletrodensidade; o gr2 também com formas arredondadas, mas com a eletrodensidade um pouco maior que o segundo. O gr3 apresenta-se mais pleomórfico e com uma eletrodensidade superior a dos demais. São observados ribossomos ( $r$ ) e mitocôndrias (m) dispersos no citoplasma. As características morfológicas descritas para este tipo celular remontam a de um neutrófilo bovino (BAGGIOLINI et al., 1985).

Na Figura 5, destaca-se a presença de uma célula com características morfológicas compatíveis a um precursor basofílico. Seu núcleo é redondo com a cromatina fina e nota-se a presença de nucléolos. Há prevalência do citoplasma em relação ao núcleo. Em seu interior observa-se a presença de grânulos muito eletrodensos e áreas com vacúolos que hipoteticamente foram preenchidos pôr estes grânulos anteriormente.

Na Figura 6, destacamos a presença de células com características morfológicas que fazem alusão a células blásticas, devido a grande relação núcleo: citoplasma, os diferentes núcleos com formato redondo e oval com a cromatina fina e pela presença de nucléolos em todas estas células. No citoplasma destas células observa-se a ausência de grânulos e a presença de mitocôndrias grandes e ribossomos dispersos em seu interior. O diâmetro destas células foi respectivamente de 10,$4 ; 10,6 ; 10,0$ $\mu \mathrm{m}$.

Segue-se abaixo a descrição das células compreendidas pelo Grupo B 
Na Figura 7, destacamos a presença de uma célula com características morfológicas compatíveis com bastonetes. Esta célula apresenta $6 \mu \mathrm{m}$ de diâmetro, núcleo em forma de bastão (contraído sem formar segmentos), e cromatina grosseira. Em seu citoplasma, são visíveis grânulos de formas arredondadas e longilíneas, com eletrodensidades semelhantes. Muitas mitocôndrias e ribossomos aparecem dispersos em seu citoplasma.

Na Figura 8, observa-se uma célula com características de um polimorfonuclear apresenta $5 \mu \mathrm{m}$ de diâmetro. Seu núcleo apresenta 2 lobos com a cromatina grosseira e agrupada; não há evidências de nucléolos. Seu citoplasma possui grânulos de formas arredondadas que diferem entre si na quantidade e na eletrodensidade com que se apresentam. Os grânulos menos eletrodensos (gr1) constituem a menor população comparados aos mais eletrodensos (gr2). Estes possuem estruturas lamelares em seu interior, de eletrodensidades diferente se comparados à dos grânulos em que estão dispostos. Essas características são sugestivas de grânulos presentes em eosinófilos maturos. Observam - se, ainda, mitocôndrias, ribossomos e polirribossomos espalhados pelo citoplasma.

Na Figura 9, é observada a presença de células precursoras eritrocíticas (er). Estas células apresentam núcleo de formato oval e cromatina muito condensada. Percebese a tendência de marginalização deste núcleo. O citoplasma destas células é claramente mais basofílico quando comparado ao citoplasma de um linfócito (lo), por exemplo. A presença de mitocôndrias dispersa no citoplasma é evidente, assim como a de ribossomos. Nota-se a presença de um reticulócitos (re) nesta foto. $\mathrm{O}$ diâmetro destas células oscilou de 4,4 a 5,5 $\mu \mathrm{m}$. Observa-se a presença de mitocôndrias, ribossomos e de vesículas de pinocitos (vp). A Figura 10 destaca as 
características de uma célula precursora eritrocítica, com morfología compatível a um metarrubrícito.

Células com características de linfócitos (lo) são observadas, na figura 9, o diâmetro destas células foi mensurado com uma média de 5,6 $\mu \mathrm{m}$ para lo1, lo2, lo3, respectivamente. A Figura 11 ilustra em um maior aumento as características morfológicas de um linfócito encontrado neste grupo. Este apresenta-se com 5,0 $\mu \mathrm{m}$, seu núcleo é redondo e chanfrado com a cromatina grosseira e agrupada. Seu citoplasma é escasso e possui mitocôndrias e ribossomos dispersos em seu interior. Próximo ao local de "reentrância" do núcleo observa-se a presença de estruturas compatíveis morfologicamente a corpúsculo de Golgi (CG).

Na Figura 12, observa-se a presença de células da série linfocítica com a forma do núcleo deformado, lembrando um trevo de quatro folhas. 


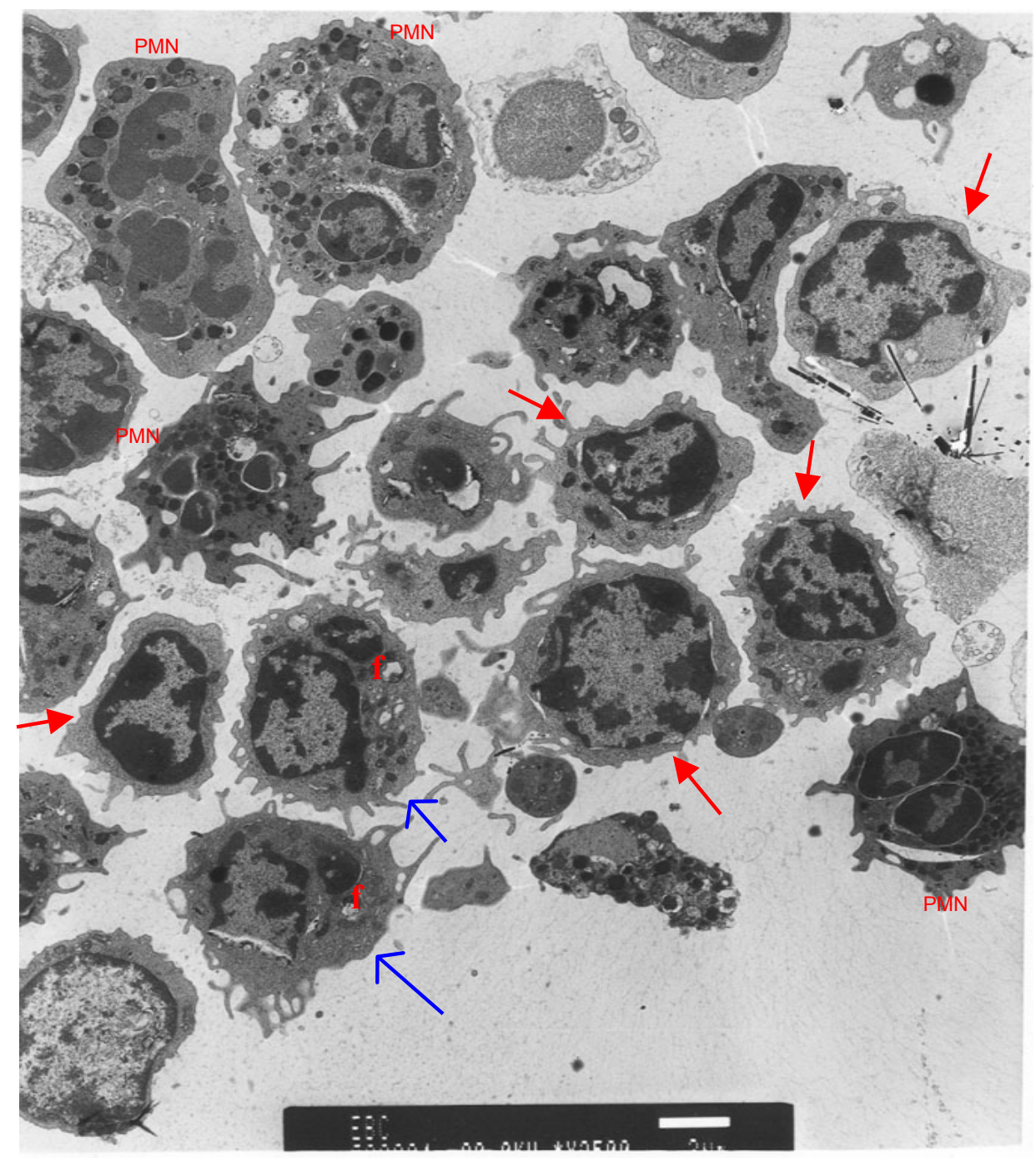

Figura 2 - Eletrofotomicrografia de transmissão de células presentes na camada leucocitária total. Polimorfonucleares (PMN), células da série linfocíticas (setas vermelhas), células em apoptose (seta azul). Apresentando uma vesícula nuclear (v) e fragmentos do núcleo (f). (Escala da barra $=2 \mu \mathrm{m})$ 


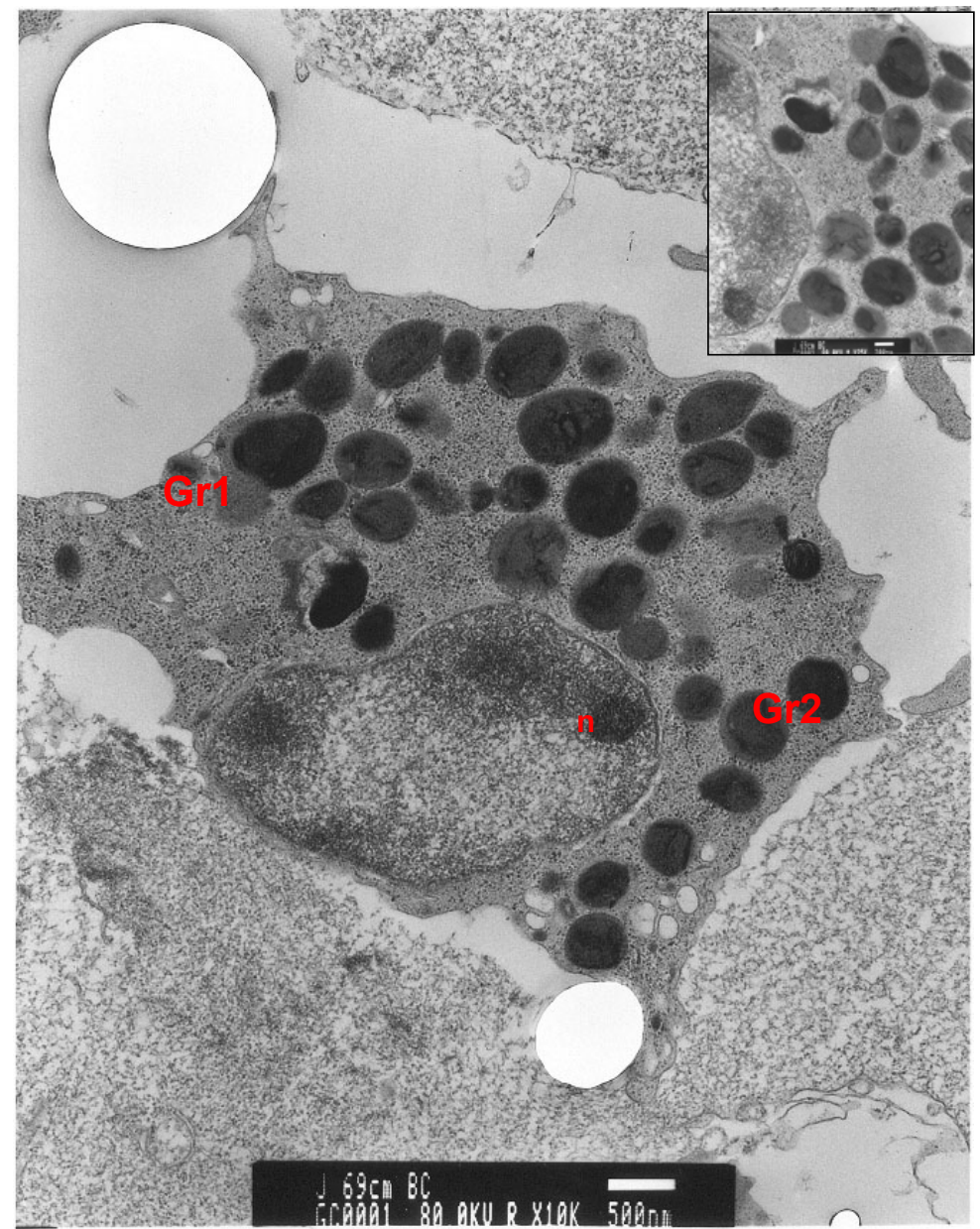

Figura 3 - Célula com característica morfológica sugestiva de um precursor eosinofílico presente na Camada Leucocitária Total. Núcleo contem nucléolo ( $\mathrm{n})$, em seu citoplasma contem dois tipos de grânulos $\mathrm{Gr}(1)$ e $\mathrm{Gr}(2)$. O $\mathrm{Gr}(2)$ possui estruturas lamelares (em evidência). (Escala da barra $=500 \mathrm{~nm}$ - barra em evidência $=200 \mathrm{~nm}$ ) 


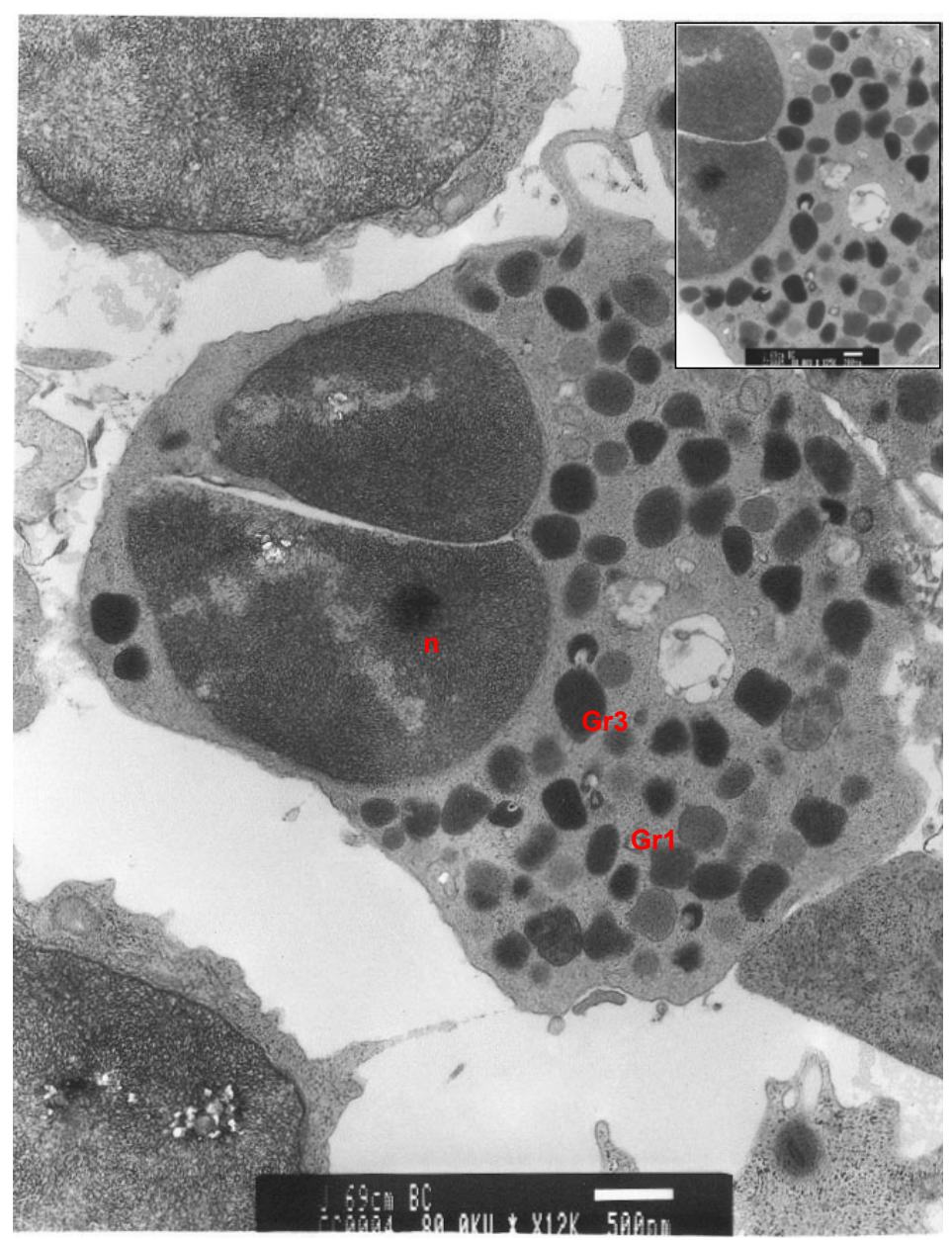

Figura 4 - Polimorfonuclear presente na Camada Leucocitária Total. Seu núcleo apresenta um nucléolo $(\mathrm{n})$ com três tipos distintos de grânulos $\operatorname{Gr}(1), \operatorname{Gr}(2)$ e $\operatorname{Gr}(3)$. Em evidência, nota-se os diferentes tipos de grânulos. (escala da barra $=500 \mathrm{~nm}$, barra em evidência $=200 \mathrm{~nm}$ ) 


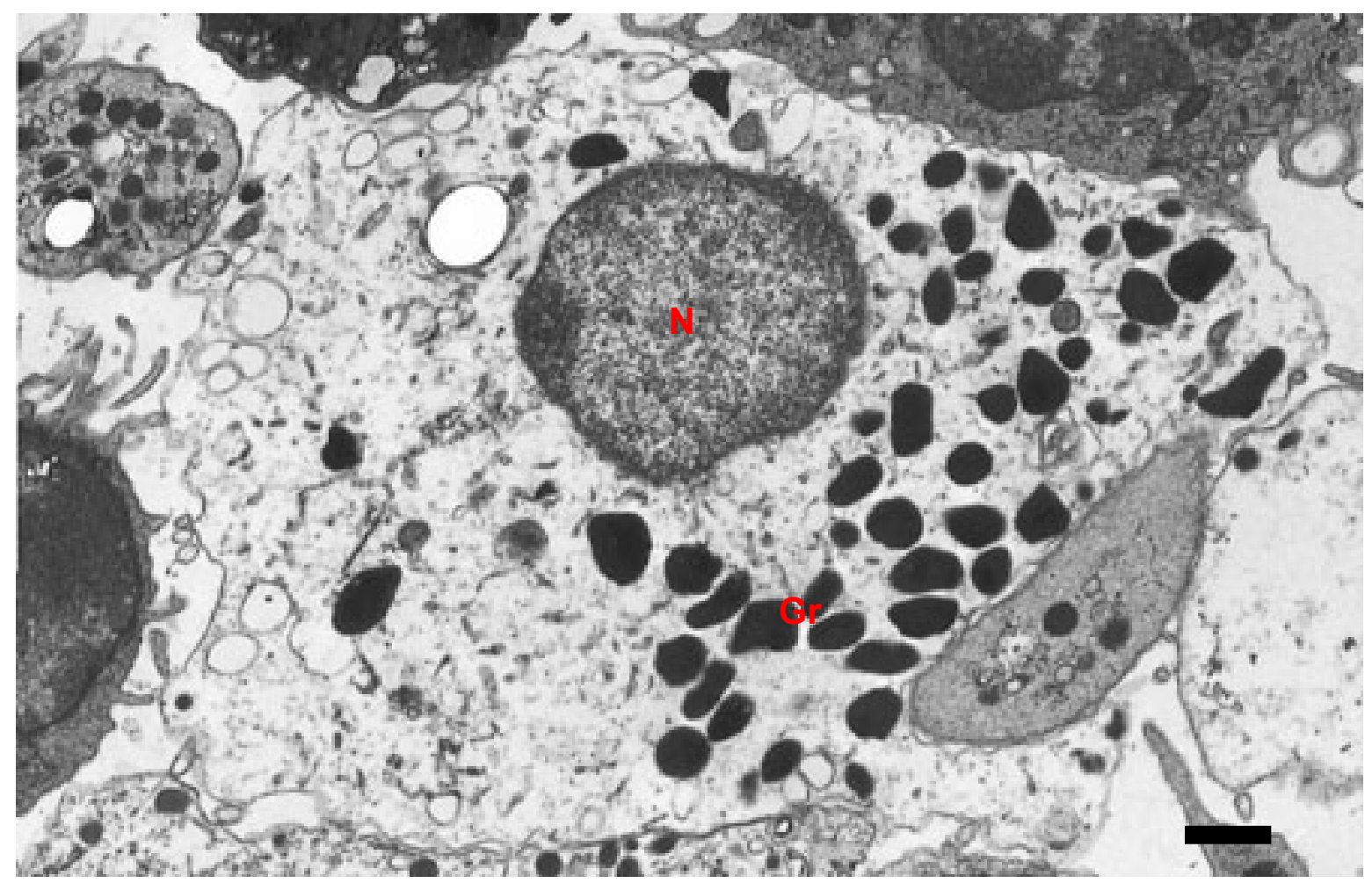

Figura 5 - Célula com características morfológicas compatíveis a um precursor basofílico presente na Camada Leucocitária Total. Em seu citoplasma nota-se a presença de grânulos $(\mathrm{Gr})$ com alta eletrodensidade $($ Escala da barra $=1 \mathrm{~cm}=2 \mu \mathrm{m})$ 


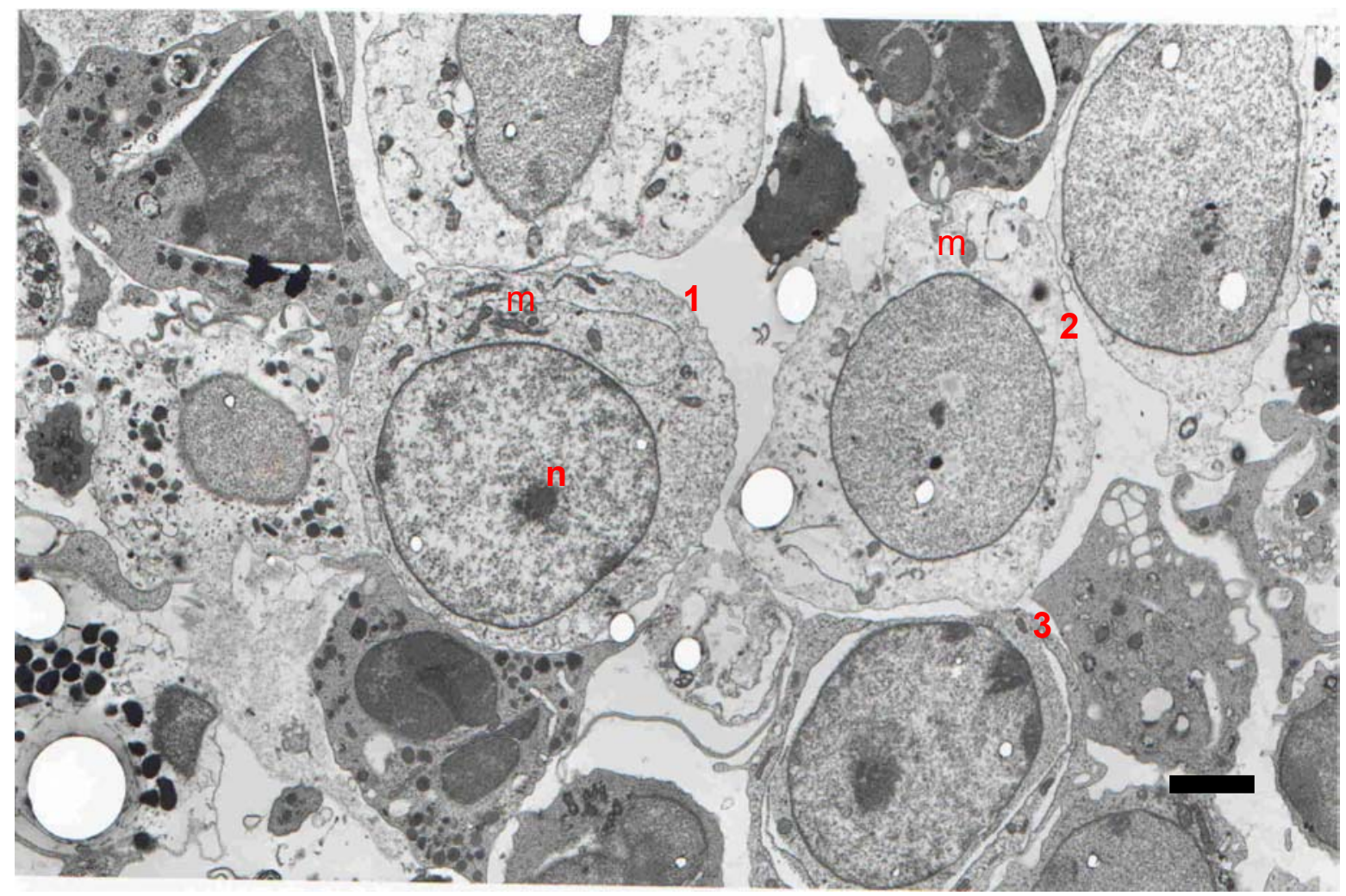

Figura 6 - Fotomicrografia de células blásticas $(1,2,3)$ presentes na Camada Leucocitária Total. Alta relação núcleo:citoplasma. No núcleo nota-se a presença de nucléolos ( $n$ ). No citoplasma estão dispersos mitocôndrias. (Escala da barra $1 \mathrm{~cm}=2 \mu \mathrm{m}$ ) 


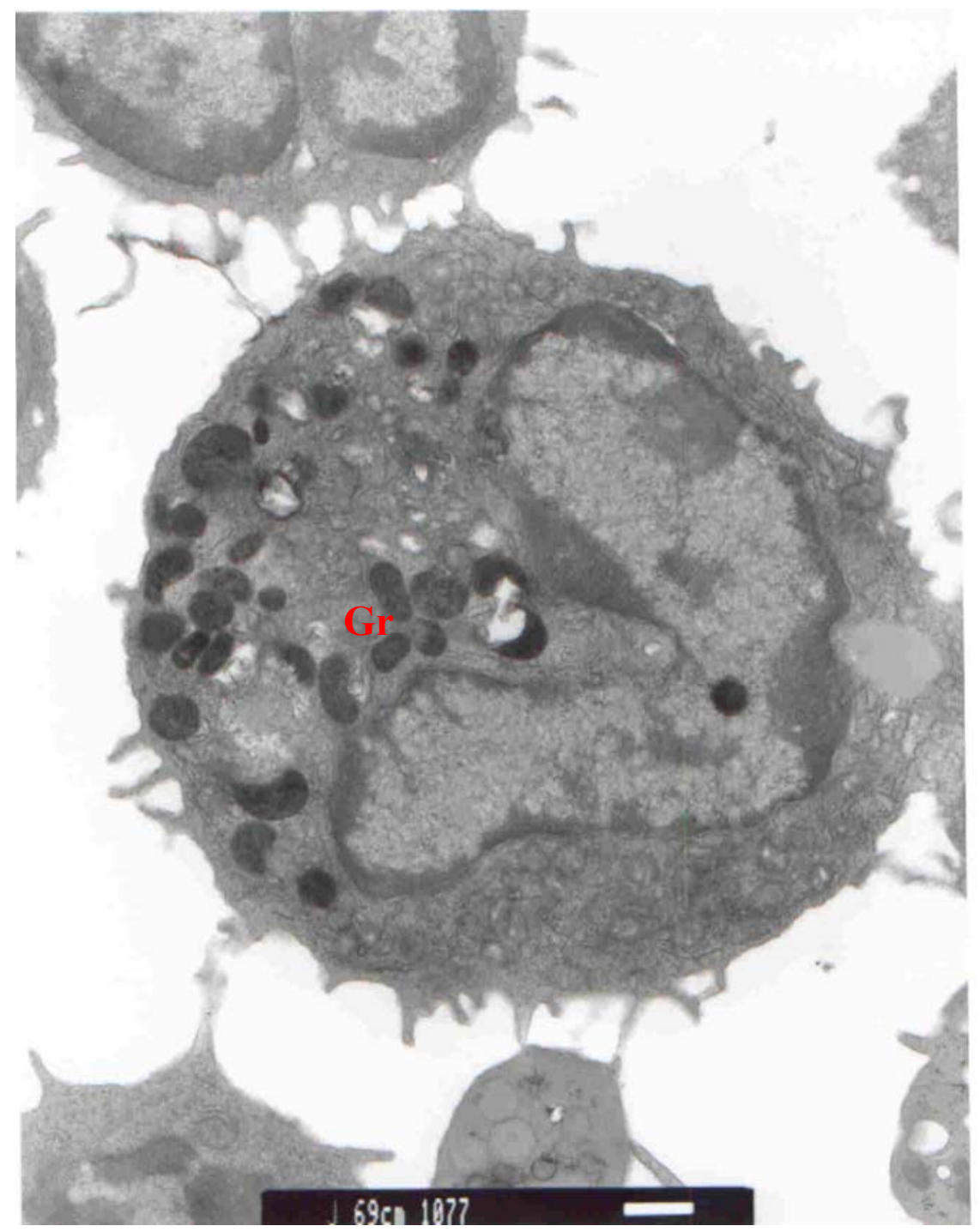

Figura 7 - Fotoeletromicrografia de um bastonete presente na interface de Ficoll Paque 1077. Nota-se a presença de um nucléolo. Em seu citoplasma estão dispersos grânulos (Gr) de formas arredondadas e longilíneas, com eletrodensidades semelhantes. (escala da barra $=500 \mathrm{~nm}$ ) 


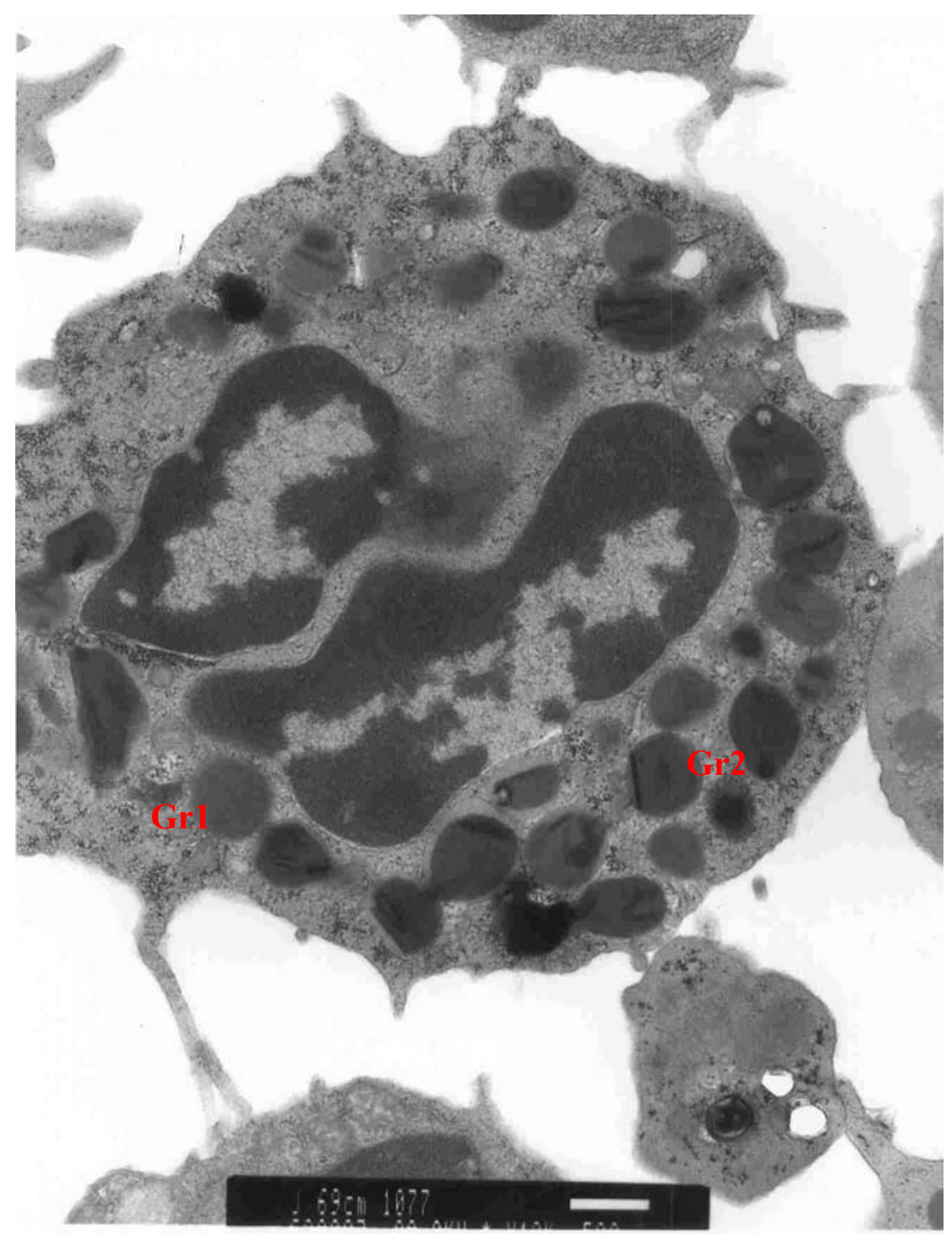

Figura 8 - Fotoeletromicrografia de um polimorfonuclear presente na interface de Ficoll Paque 1077. Nota-se a presenç a de grânulos $\operatorname{Gr}(1)$ e $\mathrm{Gr}(2)$ distintos pela eletrodensidade. $\mathrm{Gr}(1)$ apresenta eletrodensidade menor comparada ao $\mathrm{Gr}(2)$, estes possuem estruturas lamelares em seu interior (Escala da barra $=500 \mathrm{~nm}$ ) 


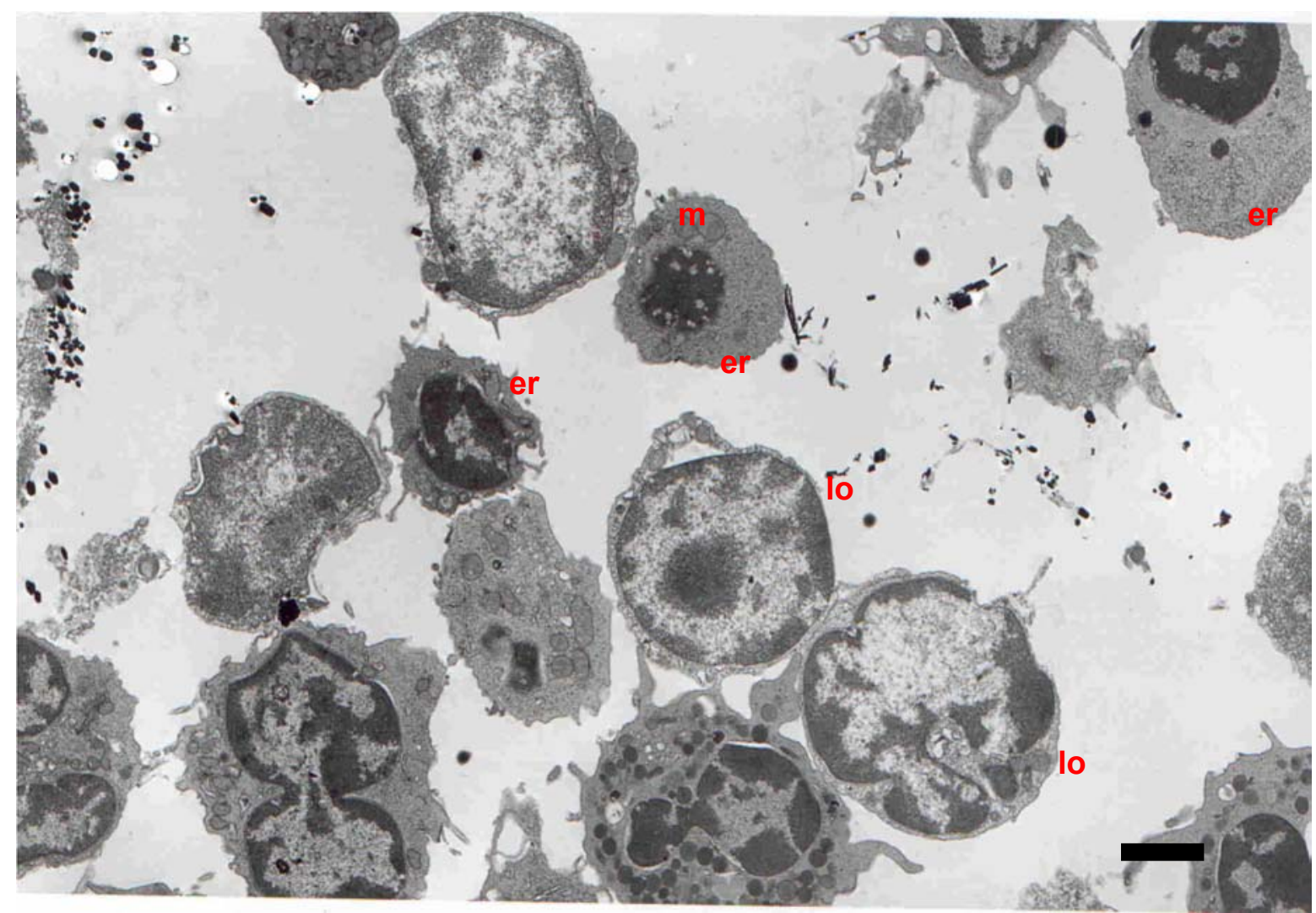

Figura 9 - Fotomicrografia de células presentes na interface do Ficoll Paque 1077. Nota-se a presença de células precursoras eritrocíticas (er), seu núcleo possui formato oval e sua cromatina muito condensada. Nota-se a presença de mitocôndrias dispersas em seu citoplasma. Células com características compatíveis a linfócitos são observadas (lo). (Escala da barra $1 \mathrm{~cm}=2 \mu \mathrm{m})$ 


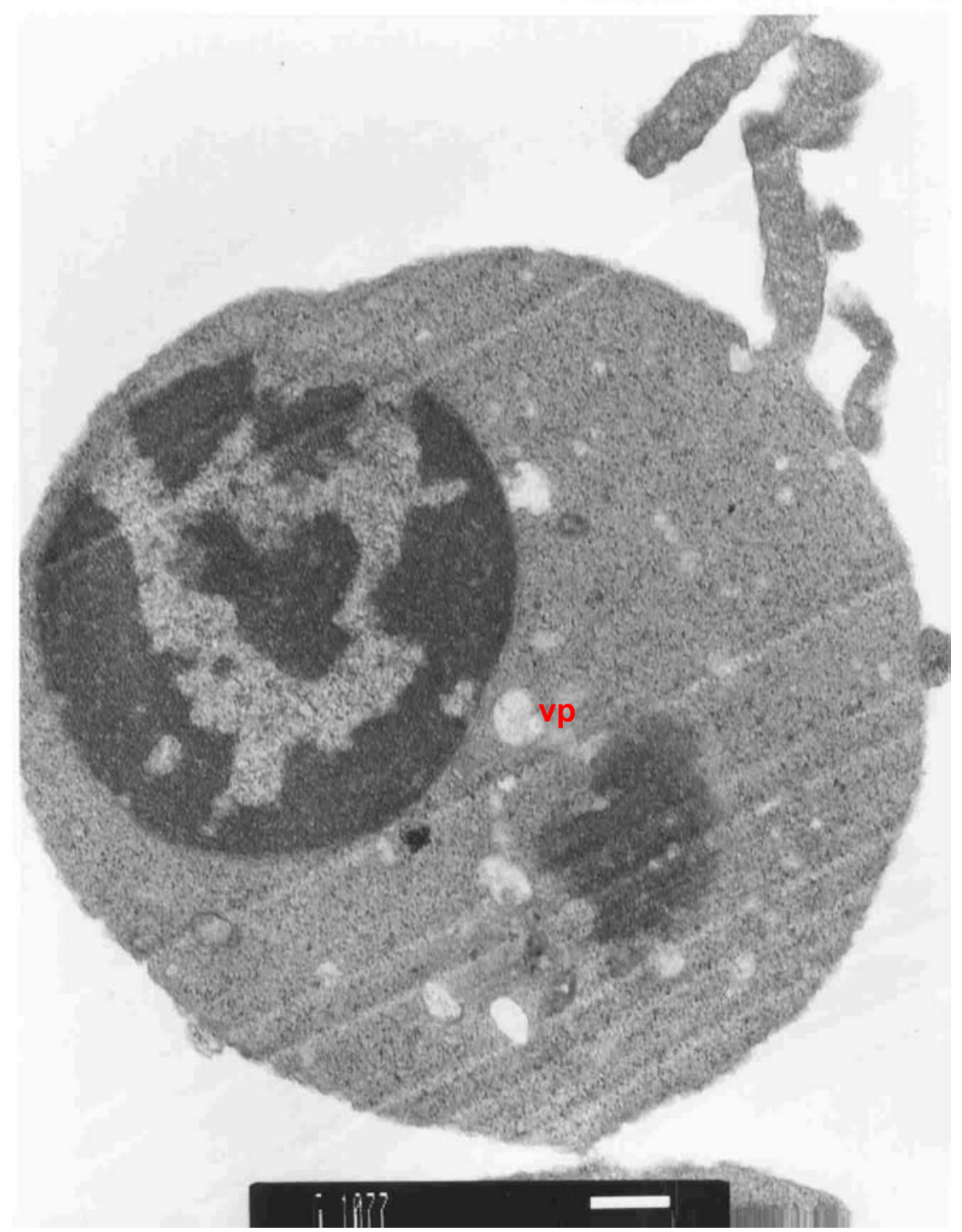

Figura 10 - Fotomicrografia de uma célula precurssora eritrocítica presente na interface de Ficoll Paque 1077. Nota-se um núcleo redondo com a cromatina muito condensada. Em seu citoplasma nota-se a presença de vesículas de pinocitose $(v p)($ Escala da barra $=500 \mathrm{~nm})$ 


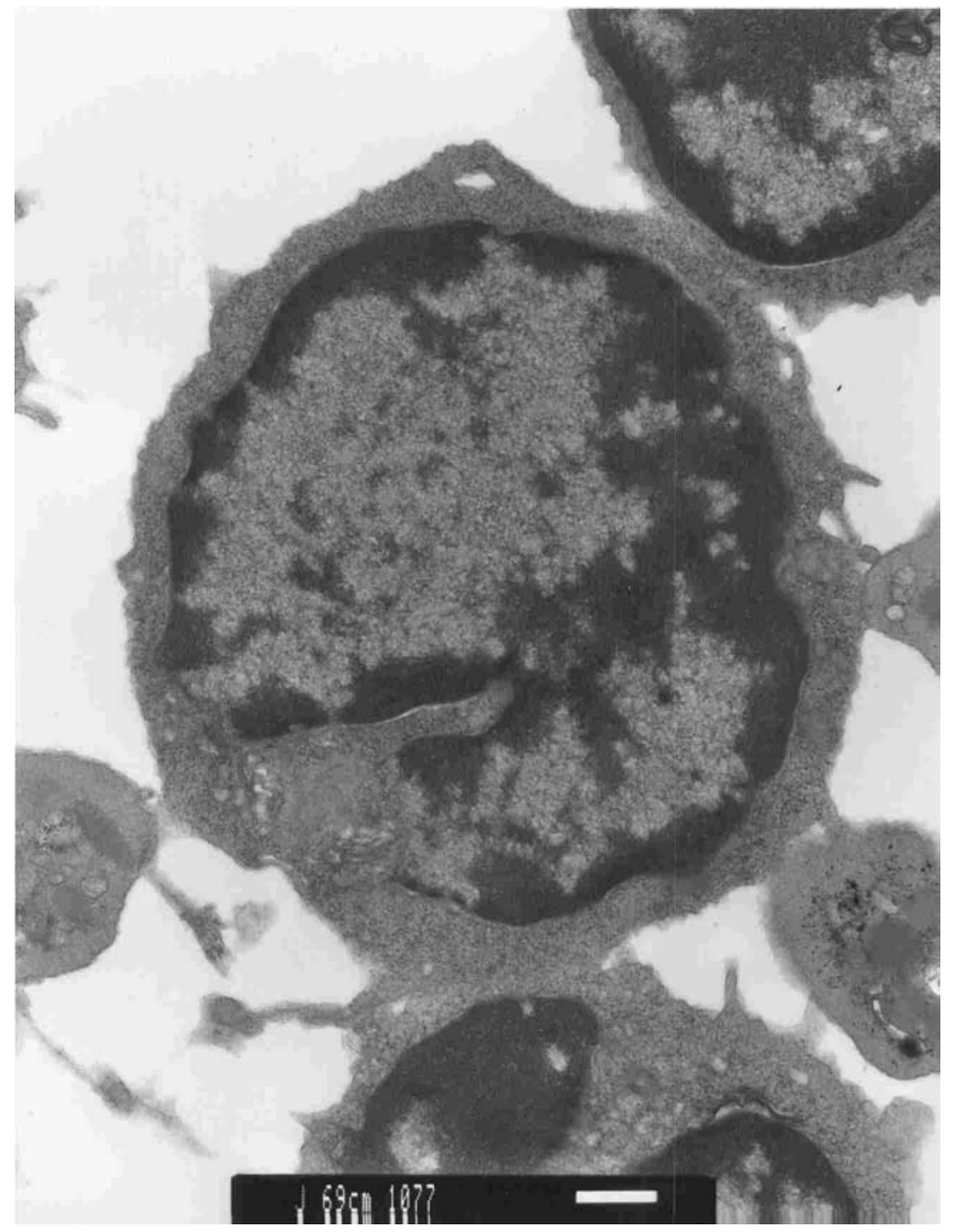

Figura 11 - Fotomicrografia de um linfócito presente na interface do Ficoll Paque 1077 (Escala da barra $=500 \mathrm{~nm}$ ) 


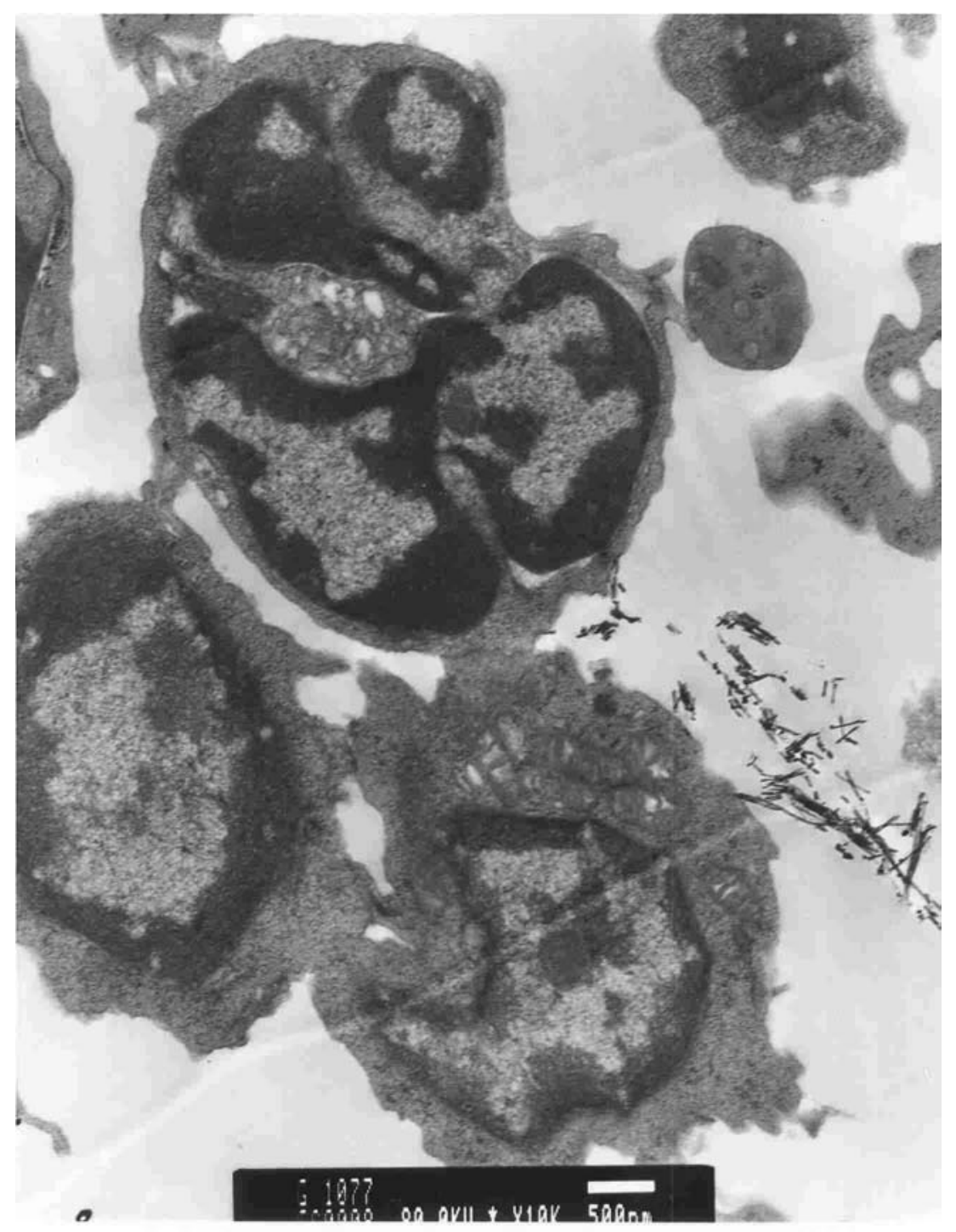

Figura 12 - Fotomocrografia de uma célula com seu núcleo em forma de trevo de quatro folhas. Presente na interface de Ficoll Paque 1077 (Escala da barra $=500 \mathrm{~nm})$ 


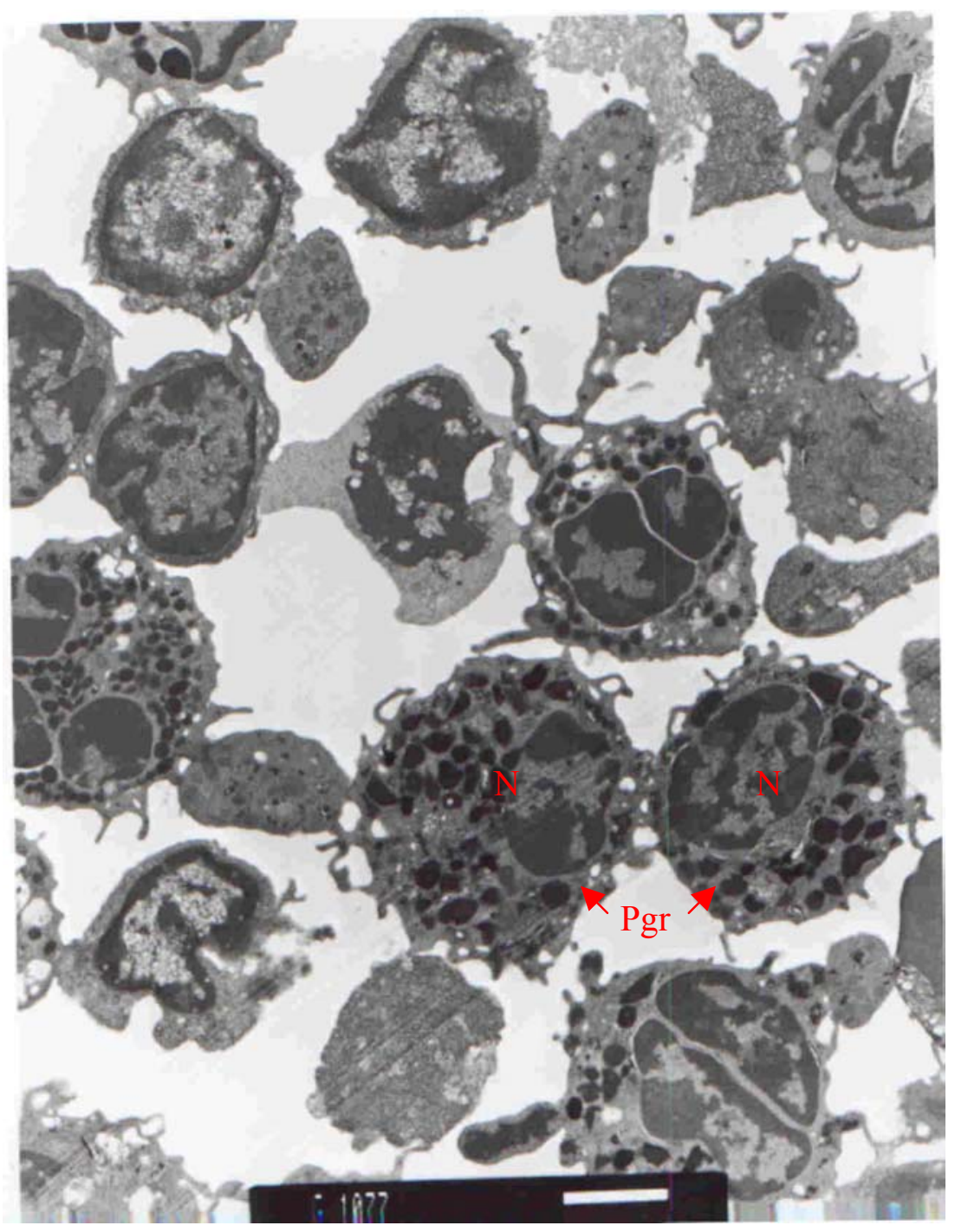

Figura 13 - Presença de células com características de um precursor granulocítico (Pgr). Seu núcleo apresenta-se com formato redondo ou oval $(\mathrm{N})$, apresentando cromatina densa (Escala da barra = $2 \mu \mathrm{m})$. 
6 DISCUSSÃO 


\section{DISCUSSÃO}

Observamos que as células de sangue de cordão umbilical de bovinos azebuados, em ambos os grupos por nós propostos, apresentaram-se com características morfológicas compatíveis com células jovens. Assim como Mikami et al. (2001), estudando as características ultraestruturais das células de sangue de cordão umbilical de seres humanos relataram a presença de células com características morfológicas compatíveis com células imaturas. Deliliers et al. (2001), em paralelo, relatam alta incidência de células CD $34^{+}$morfologicamente mais imaturas em sangue de cordão umbilical humano quando comparado com as células CD $34^{+}$ presentes no sangue periférico e na medula óssea.

A presença de células jovens no sangue de cordão umbilical de bovinos reforça as evidências de hematopoiese fetal, como já demonstrado em trabalhos científicos (ALSAMI; FILLIPICH, 1999; CARBONELL; CALVO; FIEDNER, 1982).

Destacamos, neste sentido, a presença de células blásticas (Figura 6) no sangue de cordão umbilical de bovinos; estas apresentaram uma alta relação núcleo: citoplasma; seu núcleo possui formato redondo ou oval com a cromatina fina e apresenta nucléolos em seu interior. No citoplasma destas células observam - se a ausência de grânulos e a presença de mitocôndrias grandes e ribossomos dispersos em seu interior. As características observadas nestas células são compatíveis com as descritas por outros autores (ATHENS, 1993a; CAPONE, 1964; JAIN, 1993f), principalmente, no que tange às características morfológicas encontradas no núcleo. No que diz respeito ao citoplasma, há consenso em relação à ausência de grânulos e de partículas ribonucléicas espalhadas em seu interior. O retículo endoplasmático 
não foi observado nestas células, mas, a sua presença não é constante (ATHENS, 1993a; CAPONE, 1964; JAIN, 1993f).

A presença de células vermelhas nucleadas foi evidenciada no sangue de cordão umbilical de bovinos, por nós documentada (Figuras 9 e 10), vem reafirmar as observações tecidas por diversos autores a respeito da alta incidência de células vermelhas nucleadas em fetos, principalmente no início da gestação (ALSAMl; FILLIPICH, 1999; CARBONELL; CALVO; FIEDNER, 1982; PLAYFAIR; WOLFENDALE; KAY, 1963). Estas células apresentaram características morfológicas compatíveis com as descritas por Dessypris (1993), Jain (1986), Jain (1993c) seu núcleo apresenta a cromatina condensada e com ausência de nucléolos. Seu citoplasma apresenta-se basofílico e há presença de mitocôndrias em seu citoplasma.

A presença de células com características morfológicas sugestivas de células precursoras granulocíticas (basofílica e eosinofílica) (Figuras 3,5) e de diferentes granulócitos (Figuras 2, 4, 8) já diferenciados foram evidenciadas e documentadas por nós, nos dois grupos propostos, no transcorrer do trabalho, reforçando a presença de hematopoiese ativa no feto.

As células precursoras de polimorfonucleares granulocíticos observadas apresentaram suas características nucleares compatíveis às descritas por Athens (1993a), Capone (1964) e Jain (1993f). O núcleo destas células apresentou - se com o formato redondo, cromatina fina e com a presença de nucléolo. Células com o núcleo em forma de bastão, também, foram documentadas (Figura 7). Os grânulos presentes no citoplasma dos polimorfonucleares mostraram características morfológicas compatíveis à sua linhagem. As células com morfologia sugestiva de 
precursores eosinofílicos (Figura 3) apresentaram estruturas mais radiodensas no interior de seus grânulos assim como os eosinófilos já diferenciados (Figura 8). Mikami et al. (2001), também, observaram células com grânulos morfologicamente compatíveis ao de eosinófilos em sangue de cordão umbilical de seres humanos. Células com morfologia sugestiva de um precursor basofílico apresentaram grânulos pleomórficos e muito eletrodensos. Estas características morfológicas, dos grânulos, citadas são compartilhadas com outros autores que descreveram a ultraestrutura dos grânulos presentes nos diferentes estágios de maturação dos polimorfonucleares de mamíferos (ATHENS, 1993a; CAPONE, 1964; JAIN, 1993a; JAIN, 1993b). No entanto, uma classificação do tipo de grânulo observado, como primário (azurófilo) ou secundário (específico), ficou prejudicada devido à ausência da reação da peroxidase em nosso protocolo de processamento do material. O que dificultou, também, uma classificação mais específica em relação ao estágio de desenvolvimento destas células, já que é sabido que no processo de maturação os grânulos azurofílicos ou primários surgem no citoplasma dos promielócitos. Seguidos pela aparição dos grânulos secundários, específicos às diferentes linhagens, nos mielócitos (ATHENS, 1993a; CAPONE, 1964; JAIN, 1993f). A presença de mais de um tipo de grânulos no citoplasma das células observadas sugerem que as células aqui descritas contemplam os estágios subseqüentes ao promielócito.

Observa-se a presença de células com características sugestivas de um neutrófilo (Figura 4) que apresentou em seu citoplasma a presença de três grânulos distintos. O primeiro tipo de grânulo (gr1) apresentou uma forma arredondada e eletrodensidade menor comparado ao segundo tipo (gr2). Já o terceiro tipo de grânulo (gr3) apresentou maior diâmetro e uma eletrodensidade maior aos demais. 
O que nos levou a um consenso com Baggiolini et al (1985) que descreve a presença de três tipos distintos de grânulos em neutrófilos de ruminantes.

Os linfócitos observados no sangue de cordão umbilical de bovinos apresentaram morfologia compatível àquela descrita para linfócitos maduros presentes no sangue de mamíferos. Seu núcleo apresentou forma redonda ou oval, podendo estar ligeiramente chanfrado, com a cromatina grosseira e o citoplasma escasso (Figuras 9 e 11). O diâmetro dos linfócitos apresentou - se com uma mediana de $5 \mu \mathrm{m}$, caracterizando-se assim como pequenos linfócitos segundo Jain (1983) e Jain (1993d).

Células com características morfológicas compatíveis com células em apoptose foram observadas em nosso experimento. Estas células apresentaram em seu núcleo uma formação com aparência vesicular e cromatina condensada dispersa pelo citoplasma (Figura 2); características estas descritas como compatíveis a células em apoptose (COHEN, 1993; DUVALL; WYLLIE, 1986; IHARA et al., 1998). Mikami et al. (2001) e Deliliers et al. (2001) relatam a presença de células em processo de apoptose em células de sangue de cordão umbilical. Deliliers et al. (2001) descrevem uma maior incidência destas células em sangue de cordão oriundo de fetos nascidos através de cesariana. Observam, ainda, porcentagens semelhantes de células em apoptose no sangue de cordão de fetos nascidos por parto normal e da medula óssea. Em nosso trabalho, não obtivemos dados estatísticos relacionados a células em processo de apoptose no sangue de cordão; sendo assim não possuímos parâmetro para exercer uma comparação numérica entre o sangue de cordão umbilical de bovinos e o humano, mas as evidências em relação à presença destas células no sangue de cordão umbilical de bovinos é 
indiscutível. Isso demonstra uma correlação inter espécies a este respeito. A apoptose celular está correlacionada com tecidos em que a morte celular é intrínseca a organização deste, como por exemplo, na involução de estruturas embrionárias, na atrofia de tecidos hormônio dependentes, no controle da troca tecidual (por exemplo, durante o ciclo menstrual); sendo de fundamental importância fisiológica (COHEN, 1993; DUVALL; WYLLIE, 1986). Sendo assim, sua presença no sangue de cordão umbilical, guardada as proporções, deve ser encarada com naturalidade.

Um achado interessante observado em nosso trabalho foi a presença de linfócitos apresentando o núcleo em forma de "trevo de quatro folhas" (Figura 12). Estas células foram encontradas por Mikami et al. (2001), que relacionaram a morfologia destas células com as observadas na "Sezary syndrome" e em seres humanos portadores de leucemias de célula $\mathrm{T}$.

Como pudemos notar, os resultados apresentados por este trabalho mostram, pela primeira vez, um perfil ultraestrutural das células presentes no cordão umbilical de bovinos. Estes servirão como apoio para o desenvolvimento de outras linhas de pesquisa nessa área, por exemplo, como base comparativa em modelos experimentais de cultura celular, na investigação da ontogenia de leucócitos, no desenvolvimento de anticorpos monoclonais para as células progenitoras hematopoéticas de sangue de bovinos, entre outras. 
7 CONCLUSÕES 


\section{$7 \quad$ CONCLUSÕES}

> Nosso trabalho identificou, no sangue de cordão umbilical bovino, a presença de células blásticas, células precursoras eosinofílicas, basofílicas e eritrocíticas e células pertencentes à linhagem granulocítica como: neutrófilos, eosinófilo e basófilos.

> A separação por gradiente de densidade pelo Ficoll mostrou-se eficiente no enriquecimento das células mononucleares e células precursoras granulocíticas e eritrocíticas.

> Células com características morfológicas compatíveis a células em apoptose estão presentes no sangue de cordão umbilical de bovinos. 
REFERÊNCIAS 


\section{REFERÊNCIAS}

ALSALAMI, M. T.; FILIPPICH, L. J. Haematology of foetal sheep. Australian Veteterinarian Journal, v. 77, n. 9, p. 588-594, 1999.

ATHENS, J. W. Granulocytes-Neutrophils. In: LEE, R. G.; BITHELL, T. C.; FOERSTER, J.; ATHENS, J. W.; LUKENS, J. N. Wintrobe's clinical hematology. 9. ed. Philadelphia: Lea \& Febiger, 1993a. p. 223-266.

ATHENS, J. W. Eosinophils and Basophils. In: LEE, R. G.; BITHELL, T. C.; FOERSTER, J.; ATHENS, J. W.; LUKENS, J. N. Wintrobe's clinical hematology. 9. ed. Philadelphia: Lea \& Febiger, 1993b. p. 299-310.

BAGGIOLINI, M.; HORISBERGER, U.; GENNARO, R.; DEWALD, B. Identification of three types of granules in neutrophils of ruminants. Laboratory Investigation, v. 52, n. 2, p. 151-158, 1985 .

BARONE, R. Anatomic comparée des mamiferes domestiques. Splanchnologia, v. 3, p. 579-605, 1986.

CAPONE, J.; CAPONE, E. L. W.; CHAPMAN, G. B. Electron microscope studies on normal human mieloyd elements. Blood, v. 23, n. 3, p. 300-320, 1964,

CARBONELL, F.; CALVO, W.; FLIEDNER T. M. Cellular Composition of Human Fetal Bone Marrow. Acta Anatômica, v. 113, p. 371-375, 1982.

CARR, J. H.; RODAK, B. F. Atlas de Hematologia Clínica. 1. ed. São Paulo: Santos Livraria Editora, 2000. 217 p.

COHEN, J. J. Apoptosis. Immunology Today, v. 14, p. 123-130, 1993.

DELILIERS, L. G.; CANEVA, L.; FUMIATTI, R.; SERVIDA, F.; REBULLA, P.; LECCHI, L.; HARVEN, E.; SOLIGO, D. Ultrastructuctural features of CD 34+ hematopoietic progenitor cells from bone marrow, peripheral blood and umbilical cord blood. Leukemia and Lymphoma, v. 42, n. 4, p. 699-708, 2001.

DESSYPRIS, E. N. ERYTROPOIESIS. IN: LEE, R. G.; BITHELL, T. C.; FOERSTER, J.; ATHENS, J. W.; LUKENS, J. N. Wintrobe's clinical hematology. 9. ed. Philadelphia: Lea \& Febiger, 1993. p. 134-157.

DUVALL, E.; WYLLIE, A. H. Death and the cell. Immunology Today, v. 7, n. 4, p. 115-119, 1986.

DVORACK, A. M.; FURITSU, T.; ISHIZAKA, T. Ultrastructural morfology of human mast cell progenitor in sequential coculture of cord blood cells and fibroblasts. Int. Arch. Allergy Immunol, v. 100, p. 219-229, 1993. 
EGESTEN, A.; CALAFAT, J.; JANSSEN, H.; KNOL, E. F.; MALM, J.; PERSON, T. Granules of human eosinophil leucocytes and their mobilization. Clinical \& Experimental Allergy, v. 31, n. 8, p. 1173, 2001.

EGESTEN, A.; CALAFAT, J.; WELLER, P. F.; KNOL, E. F.; JANSSEN, H.; WALZ, T. M.; OLSSON, I. Localization of granule proteins in human eosinophil bone marrow progenitors. International Archives of Allergy Immunology, v. 114, p. 130-138, 1997.

PARASKEVAS, F; FOERSTER, J. The limphocytes. In: LEE, R. G.; BITHELL, T. C.; FOERSTER, J.; ATHENS, J. W.; LUKENS, J. N. Wintrobe's clinical hematology. 9. ed. Philadelphia: Lea \& Febiger, 1993. p. 323-353.

FRITSCH, R. T.; NELSON, P.; MUIYA, P.; NAESSENS J.; BLACK, S. J. Characterization of bovine hematopoetic progenitor cells using monoclonal antibodies and fluocytoetry. Veterinarian Imunologic and Immunopatology, v. 27, p. 277-292, 1991.

GEORGE, L. L.; ALVES, C. E. R.; CASTRO, R. R. L. Histologia comparada. 2. ed. São Paulo: Roca, 1998. p. 107-137

GLUCKMAN, E.; BROXMEYER, H. E.; AUERBACH, A. D.; FRIEDMAN, H. S. ; DOUGLAS, G. W.; DEVERGIE, A.; ESPEROU, H.; THERRY, D.; SOCIE, G.; LEHN, $P$. Hematopoietic reconstitution in a pcient with Fanconi anemia by means of umbilical cord blood from an HLA-identical sibling. N Engl J Med, v. 321, p. 1174$1178,1989$.

GUNSILLUS, E.; GASTL, G.; PETZER A. L. Hematopoetic stem cells. Biomed Pharmacother, v. 55, p. 186-194, 2001.

HASTIE, R. M. B.; CHIR, B. A study of the ultrastructure of human basophil Leucocytes Laboratory Investigation, v. 31, n. 3, p. 223-231 1974.

HIKONO, H.; OHTA, M.; ZHOU, J. H.; SAKURAI, M. Expression and distribuition of Kit receptor in bovine bone marrow cells. AJVR, v. 62, n. 6, p. 974-977, 2001.

IHARA, T.; YAMAMOTO, T.; SUGMATA, M.; OKUMURA, H.; UENO, Y. The process of ultrastructural changes from nuclei to apoptotic body. Virchows Arch, v. 433, p. 433-447, 1998.

JAIN, N. M. The basophils and mast cells. In: essentials of veterinary hematology. Philadelphia: Lea \& Febiger, 1993a. p. 258-265.

JAIN, N. M. The eosinophils. In: Essentials of veterinary hematology. Philadelphia: Lea \& Febiger, 1993b. p. 247-257.

JAIN, N. M. Eritropoiesis and its regulation. In: hematology. Philadelphia: Lea \& Febiger, 1983. p. 487-513. Essentials of veterinary 
JAIN, N. M. Erytrocyte phisiology and changes in disease. In: Essentials of veterinary hematology. Philadelphia: Lea \& Febiger, 1993c. p. 133-159.

JAIN, N. M. The lymphocytes and plasma cells. In: hematology. Philadelphia: Lea \& Febiger, 1993d. p. 278-294.

JAIN, N. M. The monocytes and macrophages. In: hematology. Philadelphia: Lea \& Febiger, 1993e. p. 266-277 essentials of veterinary

JAIN, N. M. The neutrophils. In: Philadelphia: Lea \& Febiger, 1993f. p. 222-246.

Essentials of veterinary hematology.

LADIGES, W. C.; STORB, R.; THOMAS, E. D. Canine models of bone marrow transplantation. Lab Ann Sci, v. 40, n. 11, 1990.

LATSHAW; W. K. Veterinary developmental anatomy: a clinically oriented approach. Toronto: B. C. Decker, 1987. p. 69-71.

MAYANI H., LANSDROP, P. M. biology of human umbilical cord blood - Derived Hematopoetic Stem/Progenitor Cells. Stem Cells, v. 16, p. 153-165, 1988.

MONTANÉ, L.; BOURDELLE, E. Anatomie regionale des animaux domestiques. Paris: J. B. Baillière, 1917, v.2, p. 53-61.

NIEMEYER, G. P.; HUDSON, J.; BRIDGMAN, R; SPANO, J.; RICHARD, A. N.; LATHROP JR., C. D. Isolation and characterization of canine hematopoetic progenitor cells. Experimental Hematology, v. 29, p. 686-693, 2001.

CURVAS de crescimento fetal. In: NODEN, D. M.; LAHUNTA, A. Embriología de los animales domésticos: Zaragoza: Acribia, 1990. Gráficos nas páginas prefaciais.

PERTOFT, H. Fractionation of cells and subcellular particles with Percoll. $\mathbf{J}$. Biochem. Biophys. Methods, v. 44, p. 1-30, 2000.

PLAYFAIR, J. H. L.; WOLFENDALE; M. R.; KAY; H. E. M. The leukocytes of peripheral blood in the human foetus. Brit. Journal. Haematology, v. 9, p. 336-344, 1963.

RIBEIRO, A. C. M. Pesquisa anatômica sobre o funículo umbilical em bovinos azebuados. 1995. 103 f. Dissertação (Mestrado em Anatomia dos Animais Domésticos) - Faculdade de Medicina Veterinária e Zootecnia, Universidade de São Paulo, São Paulo, 1995.

ROSLER, E.; BRANDT, J.; CHUTE, J.; HOFFMAN, R. Cocultivation of umbilical cord blood cells with endothelial cells leads to extensive amplification of competent CD34+ CD38- cells. Experimental Hematology, v. 28, p. 841-852, 2000.

WEINBERG, J. B.; ATHENS, W. J. The mononuclear phagocyte system. In: LEE, R. G.; BITHELL, T. C.; FOERSTER, J.; ATHENS, J. W.; LUKENS, J. N. Wintrobe's Clinical Hematology. 9. ed. Philadelphia: Lea \& Febiger, 1993. p. 267-298. 
WYNTER, E. A.; TESTA, N.G. Interest of cord blood stem cells. Biomed.

Pharmachother, v. 55, p. 195-200, 2001.

ZAGO, M. A.; SANTIS, G. C. Sangue de cordão umbilical como fonte de células precursoras hematopoéticas. Escola Brasileira de Hematologia, v. 5, p. 151-158, 1988. 